DOI: $10.19195 / 0080-3626.60 .3$

IRENA SOCHA

\title{
NAUKA O KSIĄŻCE W POLSCE W LATACH 1945-2015. TEORETYCZNE ŹRÓDŁA INSPIRACJI
}

Główne kierunki myślowe, z właściwymi im paradygmatami i kategoriami, tworzące teoretyczny fundament nauki o książce. Zmienny zakres dyscypliny: od książki — fenomenu piśmienniczo-wydawniczego (edytorskiego), poprzez książkę w kontekstach polimedialnego komunikowania i jej funkcję społeczną, aż po społeczne relacje, działania i wartościowania tworzące kulturę książki.

SŁOWA KLUCZOWE: bibliologia, teoria bibliologii, metodologia bibliologii, nauki pokrewne bibliologii, polska szkoła bibliologiczna

Kreśląc retrospektywną panoramę teoretycznego dorobku powojennego polskiego księgoznawstwa - inspirowaną jubileuszem sześćdziesięciolecia badań i studiów bibliologicznych na Uniwersytecie Wrocławskim — podjąć trzeba przede wszystkim decyzję o porządku przedstawienia. Jeśli przyjąć uporządkowanie chronologiczne - nie połączą się w komplementarną i wyrazistą całość prace intelektualnie spokrewnione, choć od siebie czasowo odległe. W układzie problemowym - na drugim planie znajdą się wybitne osobowości tworzące intelektualny, teoretyczny potencjał dyscypliny i to nierzadko na wielu jej polach. Autorka chciała więc połączyć oba te porządki (problemowy — skupiony wokół paradygmatów sensu largo, wyznaczających główne kierunki myślenia, oraz autorski - gdy nazwa osobowa jest „firmą” określonego paradygmatu lub specyficznego zespołu problemów) jako wzajemnie się uzupełniające, a zarazem wpisać je w dynamikę diachronii. Refleksję nad kształtowaniem się kierunków bibliologicznego myślenia trzeba jednak budować nie tylko na podstawie fundamentalnych prac teoretycznych, lecz także odwołując się do prac badawczych stanowiących ich realizacje, twórcze kontynuacje bądź metodologiczne weryfikacje, które niejednokrotnie dawały istotny wkład ,teoriotwórczy”. Na czoło (cz. 1) wysunięto więc kwestię przedmiotu dyscypliny (książka — dokument), która była niemal stale obecna $\mathrm{w}$ teoretycznym myśleniu, znajdując z czasem nowe argumenty, która w konsekwencji wyznaczała główne elementy pola i zakresu badań. Dalej 
(cz. 2-6) przedstawiono kierunki badań nad książką i procesem bibliologicznym tworzące zasadniczą tradycję - fundament teorii księgoznawstwa. Na końcu te, które w ostatnich latach znacząco poszerzyły pole badań (cz. 7-9)1.

Dorobek powojennej bibliologii znany jest w ogólnym zarysie zwłaszcza dzięki tomom zbiorowym i artykułom monograficznym poświęconym jej czołowym przedstawicielom, zwłaszcza Kazimierzowi Piekarskiemu, Aleksandrowi Birkenmajerowi, Janowi Muszkowskiemu, Stefanowi Vrtelowi-Wierczyńskiemu, Adamowi Łysakowskiemu, Karolowi Głombiowskiemu, Radosławowi Cybulskiemu, Januszowi Duninowi, Krzysztofowi Migoniowi. Ogromne zasługi dla wypracowania teoretycznej tożsamości dyscypliny, w relacji do innych nauk społecznych i humanistycznych, a także dla dokumentowania jej dorobku ma K. Migoń — autor licznych prac z tego zakresu. Od lat 70. współtworzył, interpretował i porządkował refleksję bibliologiczną w Polsce w rozległym kontekście interdyscyplinarnym prac polskich i zagranicznych: rosyjskich, niemieckich, francuskich, amerykańskich i angielskich, a także czeskich i węgierskich. Fundamentalne znaczenie miała Nauka o książe. Zarys problematyki — wykład dojrzałej teorii dyscypliny w Polsce, której rozwinięcie stanowiły następne teksty autora ${ }^{2}$. Omawiając główne nurty teoretyczne oraz modele badań, porządkując metodologiczne $\mathrm{i}$ terminologiczne instrumentarium $\mathrm{w}$ odniesieniu do wysuwających się $\mathrm{w}$ danym czasie na czoło aspektów komunikacyjnych, etnicznych, medioznawczych czy antropologicznych, wskazywał Migoń na nowe potrzeby badawcze ${ }^{3}$. Poświęcając

${ }^{1}$ Autorka jest świadoma tego, że nie są to wszystkie istotne problemy teorii bibliologii, że każdy wybór, zwłaszcza w ramach tak dużej skali czasu, niesie konsekwencje pominięcia czy marginalizacji innych poglądów — przytoczone przykłady ze względu na tę wybiórczość nie składają się więc na stan badań. Wiele kierunków i problemów badawczych przedstawia i wymienia Krzysztof MIGOŃ, Bibliologia wśród innych nauk. Koncepcje, realizacje, perspektywy, [w:] Bibliologia. Problemy badawcze nauk humanistycznych. Pod red. Dariusza Kuźminy, Warszawa: SBP 2007, s. 13-24.

2 Por. K. MIGOŃ, Nauka o książce wśród innych nauk społecznych, Wrocław: Zakład Narod. im Ossolińskich - Wydawnictwo 1976; idem, Z dziejów nauki o książe, Wrocław: Zakład Narod. im. Ossolińskich 1979; idem, Nauka o książce. Zarys problematyki, Wrocław: Wydaw. Zakład Narod. im. Ossolińskich 1984; idem, O nazwie dyscypliny, która uprawiamy, Przegląd Biblioteczny (61) 1993, nr 1/2, s. 109-113; idem, Bibliologia w świecie, [w:] Wiedza o książce w nauce i dydaktyce. Konferencja, Warszawa 16-17 listopada 1999 r. Red. Małgorzata Kisilowska, Jacek Puchalski, Dariusz Kuźmina, Warszawa: Centrum Ustawicznego Kształcenia Bibliotekarzy [i in.] 2000, s. 10-25; idem, Rola terminologii w prezentacji wiedzy księgoznawczej, Przegląd Biblioteczny (71) 2003, z. 1/2, s. 77-83; idem, O wspótczesnej sytuacji badawczej w naukach o ksiązce, bibliotece i informacji, [w:] Przyszłość bibliotek w Polsce. Materiały z ogólnopolskiej konferencji, Warszawa, 12-13 października 2007 r. Red. Jadwiga Sadowska, Warszawa: Wydaw. SBP 2008, s. 69-75; idem, Bibliologia historyczna w kregu wrocławskiego bibliotekoznawstwa uniwersyteckiego, [w:] Bibliologia i informatologia. Pod red. Dariusza Kuźminy, Warszawa: Polskie Towarzystwo Bibliologiczne. Oddział Warszawski 2011, s. 47-55.

3 M.in. K. MIGOŃ, Pismo jako przedmiot badań humanistycznych, Roczniki Biblioteczne (27) 1983, z. 1/2, s. 409-433; idem, Bibliologia wobec medioznawstwa: izolacja, komplementar-

Roczniki Biblioteczne 60, 2016

(C) for this edition by CNS 
osobne studia K. Głombiowskiemu, A. Łysakowskiemu, J. Muszkowskiemu i innym, kreślił historię i teorię polskiej bibliologii. Także dzięki innym badaczom, którzy przedstawiali rozwój bibliologii w syntezach, przeglądowych artykułach, studiach wybranych aspektów, a także krytycznych recenzjach podręcznikowych opracowań, teoria dyscypliny znajdowała wielostronne oświetlenie ${ }^{4}$.

Bibliologia, której początki jako dyscypliny samodzielnej sięgają wieku $\mathrm{XVIII}^{5}$, podstawowe zręby teorii wypracowała w wieku XIX, a w pełni ukształtowała w dwudziestoleciu międzywojennym — była w kolejnych dziesięcioleciach nauką dynamicznie się rozwijającą, weryfikującą definicje przedmiotu badań, a zwłaszcza granice swojego pola wobec intelektualnych wyzwań innych nauk humanistycznych i społecznych, z którymi łączyły ją pokrewne problemy i nieostro wyznaczone pogranicza. Tym, co wobec stale nowych inspiracji i wielokierunkowych poszukiwań określało jej constans, była tyleż dyskursywna teoria, co warsztat badawczy — metody identyfikacji druków i rękopisów, klasyfikowania dokumentów, badania księgozbiorów itp., zweryfikowane wielokrotnie w tradycji badawczej, mające precyzyjną wykładnię źródłową i metodologiczną, a więc to, co według propozycji Barbary Bieńkowskiej tworzy bibliologię sensu stricto ${ }^{6}$. Za-

ność czy integracja, [w:] Książka i prasa w systemie komunikacji społecznej. Przeszłość, dzień dzisiejszy, perspektywy. Pod red. Marii Judy, Lublin: Wydaw. UMCS 2002, s. 13-18; idem, Kultura książki. Program dla bibliologii i potrzeba dla studiów bibliotekoznawczych, [w:] Nauka o książce, bibliotece i informacji we wspótczesnym świecie. Red. Marianna Banacka, Warszawa: Wydaw. SBP 2003, s. 11-20; idem, Książka w perspektywie etnicznej, [w:] Kultura książki ziem wschodniego i południowego pogranicza Polski (XVI-XX wiek). Paralele i różnice. Red. Jolanta Gwioździk, Edward Różycki, Katowice: Uniwersytet Śląski 2004, s. 13-27; idem, Uniwersum piśmiennictwa, jego właściwości, granice i sposoby istnienia, [w:] Uniwersum piśmiennictwa wobec komunikacji elektronicznej. Red. Krzysztof Migoń i Marta Skalska-Zlat, Wrocław: Wydaw. Uniwersytetu Wrocławskiego 2009, s. 11-20.

${ }^{4}$ M.in. Barbara BIEŃKOWSKA, Bibliologia i okolice, [w:] E scientia et amicitia. Studia poświęcone profesorowi Edwardowi Potkowskiemu. W sześćdziesięciopięciolecie urodzin i czterdziestolecie pracy naukowej. Warszawa-Pułtusk: Wyższa Szkoła Humanistyczna 1999, s. 41-47; eadem, Bibliologia dyscyplina rozwojowa, [w:] Bibliologia i informatologia ..., s. 13-22; Maria JUDA, Bibliologia historyczna: między tradycja a nowymi perspektywami, [w:] Bibliologia i informatologia..., s. 23-29; Paulina BUCHWALD-PELCOWA, Historia ksiażki a historia literatury, [w:] Historia literatury i historia ksiązki. Studia nad książka i literaturą od średniowiecza po wiek XVIII, Kraków: Universitas 2005, s. 7-24.

5 Anna ŻBIKOWSKA-MIGOŃ, Historia ksiązki w XVIII wieku. Poczatki bibliologii, Warszawa: PWN 1989; Bożena KOREDCZUK, Poczatki teorii bibliologii. Dictionnaire raissoné de bibliologie' (1802-1804) Gabriela Etienne'a Peignota. Analiza i recepcja, Wrocław: Wydaw. Uniwersytetu Wrocławskiego 2005.

${ }^{6}$ B. BIEŃKOWSKA, Bibliologia i okolice..., s. 45. Jej podstawę stanowiła teoria nauki o książce w ujęciu Aleksandra Birkenmajera, dla którego bibliologia była specjalistyczną wiedzą o materialnej postaci książki, badanej jednak w dynamice społecznego obiegu: księgarskiego, bibliotecznego i czytelniczego, wykluczając kwestie treści książki i jej wpływu na odbiorców. (eadem, Aleksandra Birkenmajera koncepcja historii książki, Przegląd Biblioteczny (46) 1978, z. 2, s. 155-162); eadem, Bibliologia dyscyplina rozwojowa..., s. 15. 
razem pokrewieństwa koncepcji i kategorii wypracowanych na gruncie bibliologii oraz innych dyscyplin humanistycznych i społecznych świadczą nie tylko o istnieniu wzajemnych wpływów intelektualnych oraz warsztatowych, lecz przede wszystkim o stale dokonującym się procesie pogłębiania multidyscyplinarnego oglądu jako normy i warunku naukowej prawdy?

1. Książka czy dokument (zapis graficzny) — to pytanie o główny obiekt, a w konsekwencji przedmiot i zakres bibliologii ${ }^{8}$, lokuje się także w bogatej tradycji historycznych i historycznokulturowych badań teorii piśmienności, ukazujących zjawiska cywilizacyjne, technologiczne i zarazem mentalne towarzyszące procesom alfabetyzacji, przechodzeniu od kultury oralnej do kultury pisma, a dalej do komunikacji medialnej ${ }^{9}$. Pojawienie się cyfrowych postaci tekstu, komplementarne korzystanie przez odbiorców z wielu form zapisu i „kanałów” piśmiennej komunikacji ${ }^{10}$ oraz rozwój teorii informacyjnych zaktualizował problem: czy obiektem tym jest książka (rękopiśmienna i drukowana) w wielu historycznokulturowych postaciach swojej edytorskiej egzystencji, czy też dokument piśmienniczy (zapis graficzny) jako społecznie funkcjonujący komunikat rejestrujący wszelkie przejawy kultury, ku czemu skłaniała się w początkach XX wieku głównie szkoła belgijsko-francuska (Paul Otlet, Robert Estivals), choć źródła koncepcji dokumentologicznych widzieć trzeba nawet stulecie wcześniej (G. Peignot) ${ }^{11}$.

Na gruncie polskiej bibliologii kierunki poszukiwań inspirowane fenomenem książki i piśmiennej komunikacji pojawiały się głównie w odniesieniu do badań czytelnictwa (na pograniczach z socjologią i językoznawstwem) ${ }^{12}$ bądź w polu

${ }^{7}$ K. MIGOŃ, Bibliologia wśród innych nauk...

8 K. MIGOŃ, Pismo jako przedmiot badań...; Edward POTKOWSKI, Rękopis a druk. Przełom w dziejach techniki czy dziejach cywilizacji?, Przegląd Biblioteczny (69) 2001, z. 3, s. 185-198.

9 Wiele z prac obcojęzycznych poświęconych tym zagadnieniom (m.in. takich autorów, jak: Jack Goody, Elisabeth Eisenstein, Walter Ong, Eric Havelock, Robert Escarpit, Marshall McLuhan, Umberto Eco, Marc Lipovetsky, Jean Serroy) znalazło polski przekład, m.in. w serii Communicare. Historia i kultura. Pod red. Andrzeja Mencwela. W Polsce badania alfabetyzacji prowadzili m.in. historycy (Wacław Urban, Janusz Tazbir, Ewa Wipszycka, Andrzej Wyczański) oraz językoznawcy (Aldona Skudrzyk).

${ }_{10}$ Zjawisko określane przez socjologów kultury jako meta-reading. Zob. Roman CHYMKOWSKI, Czytanie z ekranu - wstęnny zarys problematyki, Przegląd Humanistyczny (46) 2002, nr 1, s. 120-121.

${ }^{11}$ K. MIGOŃ, Paul Otlet o bibliologii, ksiażce i dokumencie, [w:] Przestrzenie informacji i komunikacji społecznej. Red. Maria Kocójowa, Kraków: UJ 2004, s. 370-376; idem, Bibliologia wśród innych nauk..., s. 24. K. Migoń wyjaśnia, że mimo innej terminologii („cywilizacja piśmienna”, „cywilizacja książki”) w pracach współczesnych badaczy frankofońskich (jak R. Estivals, Jean Meyriat, Brigitte Richter) są one pojęciowo tożsame z „kulturą książki” ('Kultura książki' wyrażenie potoczne, kategoria badawcza czy specjalność naukowa?, [w:] Ludzie i książi. Studia i szkice bibliologiczno-biograficzne. Ksiegga pamiatkowa dedykowana Profesor Hannie Tadeusiewicz. Red. Ewa Andrysiak, Łódź: Wydaw. Ibidem 2011, s. 47-57).

12 Zob. Bożena HOJKA, Język i pismo w kontekście powiązań interdyscyplinarnych nauki o książce, [w:] Biblioteki, informacja, książka: interdyscyplinarne badania i praktyka XXI wieku, 
specjalistycznych badań paleograficznych nad rozwojem edytorskich systemów liternictwa ${ }^{13}$. W okresie międzywojennym badania nad pismem łączono z praktycznymi aspektami nauki czytania warunkowanej m.in. grafiką książki - liternictwem i innymi cechami jej edytorskiego wyposażenia ${ }^{14}$. Specyficzne dla nauki o książce problemy dokumentologii jako subdyscypliny typologizującej i klasyfikującej dokumenty (książki, broszury, czasopisma, dżs-y, e-booki) ${ }^{15}$ oraz porządkującej ich zasoby, bliskiej ze względu na użyteczność zarówno bibliotekarstwu, jak i informacji naukowej, nieobce były teorii J. Muszkowskiego ${ }^{16}$. Również J. Dunin, ukazując różnorodność kulturowych postaci i funkcji książki, jej wielopostaciową i amorficzną naturę od tandetnych broszurek po bibliofilskie cimelia, podważał te definicje, które jedynie w cechach strukturalnych chciałyby poszukiwać jej tożsamości ${ }^{17}$. Dariusz Grygrowski na pograniczu zagadnień bibliotekarstwa, informologii i bibliologii, w rozległym kontekście cywilizacyjno-kulturowych aspektów współczesnej net-kultury analizował zagadnienia klasyfikacji, typologii i przechowywania bibliotecznych dokumentów nieksiążkowych, dając bogaty materiał do dyskusji nad możliwościami rozwoju współczesnych zasobów i systemów informacji, a także przeobrażeniami samej książki oraz w konsekwencji — odbiorczych praktyk ${ }^{18}$.

ePublikacje Instytutu Informacji Naukowej i Bibliotekoznawstwa Uniwersytetu Jagiellońskiego, seria III. Red. Maria Kocójowa, Kraków 2010, nr 7, s. 166-172.

13 Np. E. POTKOWSKI, Pismo i społeczeństwo w kulturze polskiego średniowiecza (XIVXV wiek), Przegląd Humanistyczny (22) 1978, z. 12, s. 35-52; idem, W kręgu średniowiecznej książki. Książka rękopiśmienna jako obiekt badań bibliologii historycznej, [w:] Bibliologia i informatologia..., s. 31-46; Jan SŁOWIŃSKI, Badania paleograficzne nad nowożytnymi dziejami pisma tacińskiego (XVI-XVIII w.), [w:] Profile nauki o książce. Red. Jan Pomorski, Lublin: UMCS 1988, s. 67-110; Maria JUDA, Pismo drukowane w Polsce XV-XVIII wieku, Lublin: UMCS 2001.

${ }^{14}$ Hanna DOBROWOLSKA, Grafika książki a czytanie, Warszawa: ZBP 1933; eadem, Technika czytania a czytelnictwo, Warszawa 1938. Bogaty dorobek w zakresie badań nad liternictwem, układem typograficznym książki i jego estetyką mają w Polsce graficy: wiele tekstów na ten temat ukazało się w czasopismach „Litera” (dodatek „Poligrafiki” — poświęcony sprawom liternictwa, czcionek i matryc drukarskich, Warszawa, 1966-1978) oraz „Świat Druku” (Łódź: Polski Drukarz, 1993-).

15 Ewa PITAK, Klasyfikacja piśmiennictwa w nauce o książce, Studia o Książce (8) 1978, s. 27-41; K. MIGOŃ, Rola terminologii...; Druki ulotne i okolicznościowe: wartości i funkcje. Materiały międzynarodowej konferencji naukowej, Wojnowice, 8-10 października 2004. Red. nauk. Krzysztof Migoń, Marta Skalska-Zlat, Anna Żbikowska-Migoń przy współpr. Elżbiety Herden, Wrocław: Wydaw. Uniwersytetu Wrocławskiego 2006.

16 Zob. Jacek LADORUCKI, System książki Jana Muszkowskiego, [w:] Jan Muszkowski. Ludzie, epoka, ksiązki. Tradycje i kontynuacje. Red. Grzegorz Czapnik, Zbigniew Gruszka, Jacek Ladorucki, Łódź-Warszawa: Wydaw. Uniwersytetu Łódzkiego i SBP 2014, s. 33, 37.

17 Janusz DUNIN, Pismo zmienia świat. Czytanie, lektura, czytelnictwo, Warszawa-Łódź: PWN 1998, s. 28. Zajmował w tym względzie przeciwne stanowisko niż K. Głombiowski, co zapewne wynikało również z kulturowych odmienności postaci dokumentów w epokach, które badali.

18 Dariusz GRYGROWSKI, Dokumenty nieksiążkowe w bibliotece, Warszawa: Wydaw. SBP 2001.

Roczniki Biblioteczne 60, 2016

(C) for this edition by CNS 
Wśród odpowiedzi na zasadnicze pytanie o obiekt — definiowany czy to jako dokument komunikacji piśmiennej (papierowy lub elektroniczny), czy jako książka (a więc dokument o określonych cechach edytorskich umożliwiających jego społeczne użytkowanie) — i wynikający stąd przedmiot badań bibliologii, historycznie przeważała druga opcja: stawiająca książkę, przede wszystkim w najtrwalszej historycznie formie kodeksu, oraz właściwe jej procesy i aspekty produkcji, morfologii i estetyki, rozpowszechniania i konsumpcji w centralnym polu badań (J. Muszkowski, K. Głombiowski) ${ }^{19}$. Wcześnie pojawiły się jednak próby stawiania na tym miejscu pisma zmaterializowanego $\mathrm{w}$ postaci dokumentu jako narzędzia społecznej komunikacji, otwierając drogę dokumentologii, a współcześnie poszukiwaniu wspólnych miejsc z informologią ${ }^{20}$. Szerokiemu definiowaniu książki, otwartemu na wszelkie jej postacie materialne i formalne, przysłużył się, ze stanowiska bibliotekarza i bibliografa, S. Vrtel-Wierczyński, wyróżniając trzy kategorie „przedmiotów bibliologicznych” z coraz mniejszym udziałem tekstu pisanego: obok książek sensu stricto, książki sensu largo (nuty, grafika, druki ulotne, plakaty, programy) oraz materiały dokumentujące różne aspekty życia (dyplomy, znaczki pocztowe, karty do gry, filmy, fotografie, płyty) ${ }^{21}$. Do Vrtela-Wierczyńskiego nawiązał później R. Cybulski, lokując definicję i zakres pojęciowy „książki” w trzech polach: książka sensu stricto (w postaci kodeksu); sensu largo - ponadto wszelkie dokumenty pełniące, mimo zróżnicowanej formy, funkcję książki; pozostałe dokumenty występujące w komunikacji społecznej na różnych nośnikach (np. ikonografia, mapy, filmy) ${ }^{22}$. Za szerokim rozumieniem terminu „książka” opowiadał się A. Łysakowski ${ }^{23}$. Stanowisko semiotyczne stało

19 Wydaje się, że Muszkowski dostrzegając inspiracje dokumentologiczne (zob. jego tekst Dokumentacja i dokumentologia, 1947) oraz możliwą opozycję książka-dokument piśmienniczy, budował definicję książki otwartą na inne postaci utrwalenia tekstu jako: ,produkt materializacji graficznej treści kulturowych, stanowiących pewną zamkniętą całość, materializacji podjętej w celu utrwalenia tych treści, przekazania ich i rozpowszechnienia wśród ludzi” (Jan MUSZKOWSKI, Książka jako przedmiot nauki, Bibliotekarz 1948, nr 10/11, s. 151) czy: „Wszelkie zanotowanie pewnej treści bez względu na to, jaki proces materializacji graficznej został zastosowany...” (idem, Książka jako zjawisko społeczne, [w:] Studia nad książka poświęcone pamięci Kazimierza Piekarskiego. [Red.] Kazimierz Budzyk i Alodia Gryczowa, Wrocław: Wydaw. Zakładu Narod. im. Ossolińskich 1951, s. 79).

20 Por. K. MIGOŃ, Pismo jako przedmiot...; idem, Uniwersum piśmiennictwa...; Małgorzata GÓRALSKA, Kryzysy informacyjne, rewolucje medialne i ich wplyw na rozwój piśmienności, [w:] Bibliologia i informatologia... s. 239-250.

21 Stefan VRTEL-WIERCZYŃSKI, Teoria bibliografii w zarysie, Wrocław: Wydaw. Zakład Narod. im. Ossolińskich 1951; K. MIGOŃ, Stefana Vrtela-Wierczyńskiego koncepcja bibliologii, Roczniki Biblioteczne (28) 1984, s. 3-13.

22 Radosław CYBULSKI, Struktura i właściwości książki, Studia o Książce (14) 1984, s. $34-35$.

${ }^{23}$ K. MIGOŃ, Centralne kategorie bibliologii Adama Lysakowskiego, [w:] Adam Eysakowski, bibliotekarz, bibliograf, bibliolog. Materiaty z sesji jubileuszowej, Warszawa, 10 września 2002, Warszawa: Biblioteka Narodowa 2003, s. 43-52. 
u podstaw „poszerzonej” definicji komunikatu w syntezie badań bibliologicznych i literaturoznawczych zaprezentowanej przez Janusza Kosteckiego ${ }^{24}$. K. Migoń przyjmuje, że „Nowoczesna bibliologia jest nauką o strukturze i właściwościach komunikacji za pośrednictwem zapisu graficznego" 25 — bez względu na rodzaj nośnika, zarówno w przeszłości, jak i współcześnie. Stanowiska te dowartościowują w przedmiocie badań sam proces piśmiennej komunikacji (jego postać, przebieg, bariery, skuteczność, skutki), co prawda w ścisłej zależności od postaci dokumentu jako nośnika oddziałującego na komunikacyjny potencjał przekazu.

Badania nad dokumentem piśmienniczym, choć nie znalazły jeszcze na gruncie polskiej bibliologii zamknięcia w skończonej koncepcji teoretycznej, obejmowały wiele aspektów: od specjalistycznych studiów paleograficznych, przez prace z zakresu typologii i klasyfikacji dokumentów piśmienniczych, obserwacje procesu percepcji grafiki pisma w procesie czytania, badania zjawiska alfabetyzacji oraz językowej kompetencji co do werbalizacji lekturowego doświadczenia, po monografie księgoznawcze analizujące pismo jako wyraz materialnej postaci książki i jej estetyki, potwierdzając „otwartość” i „pojemność” dyscypliny jako cechę wyróżniającą. Współistnienie w wielorakich środowiskach społecznych i publicznościach kulturowych różnych postaci komunikacji „książkowej” i ,paraksiążkowej” (dokumentowanej drukami okolicznościowymi, aktywnością retoryczną i rękopiśmienną, później czasopiśmienniczą, a współcześnie sieciową) inspiruje do wielu jeszcze pytań — zarówno teoretycznych, jak i badawczych. Kulturowa i „dokumentologiczna” perspektywa oglądu komunikacji piśmiennej stoją przed wyzwaniem harmonizowania teoretycznych warsztatów opcji książko- i pismocentrycznej. Jest to ważne nie tylko w odniesieniu do współczesnej wielomedialnej komunikacji kulturowej, lecz także do badań historycznych. W dziejach polskiej kultury komunikacja rękopiśmienna (korespondencja, notesy lektury, pamiętniki itp.) oraz retoryczna (komentowanie, kontynuowanie, dyskutowanie, żywe obrazy) jako komplementarne wobec „drukowanej”, współistniały znacznie dłużej, niż się przyjmuje, oceniając z punktu widzenia technologii ${ }^{26}$. Refleksja dostrzegająca współzależność tych form pojawiła się w pracach Małgorzaty Komzy, badającej w perspektywie komunikacyjnej zjawiska z pogranicza

24 „Nie ulega wątpliwości, że aby w sposób pełny opisać uczestnictwo w kulturze ludzi [...] należy na tych samych prawach traktować wszystkie teksty kultury, realizowane w różnym materiale semiotycznym, przekazywane przy pomocy różnych technik komunikacyjnych" (Janusz KOSTECKI, Charakterystyka wybranych społecznych sytuacji komunikacji czytelniczej w polskiej kulturze czytelniczej II połowy XIX wieku. Sesja naukowa nt. Spoleczne uwarunkowania instytucjonalne życia literackiego, Warszawa-Olsztyn: IBL PAN Warszawa, WSP Olsztyn 1977, s. 5).

${ }^{25} \mathrm{~K}$. MIGOŃ, O nazwie dyscypliny..., s. 111-112.

26 Jak istotny jest ten wymiar komunikacji kulturowej i jak poszerza horyzonty księgoznawczej perspektywy świadczy np. tekst Alberta GORZKOWSKIEGO, Qui legit, intelligat. Refleksje o retorycznych modelach lektury w kulturze i literaturze dawnej, Pamiętnik Literacki (94) 2003, z. 1, s. 5-25. 
estetyki książki (pisma) i estetyki obrazu ${ }^{27}$. Współistnienie różnych postaci komunikacji książkowej, rękopiśmiennej, ikonograficznej i retorycznej na bogatym materiale dokumentacyjnym kultury książki środowisk zakonnych obrazuje Jolanta Gwioździk ${ }^{28}$.

2. „Życie książki”. Największy bodaj zasięg i najdłuższą egzystencję, począwszy od lat 30 . XX wieku, miały teorie bibliologiczne kierunkujące myślenie wokół paradygmatu definiującego książkę jako proces, według porządku produkcji, rozpowszechnienia i konsumpcji, co znalazło przedstawienie w myśli teoretycznej K. Piekarskiego. Na fundamencie inspiracji socjologicznych, jakie w nauce o książce pojawiły się w latach 30. XX wieku (Stanisław Orsini-Rosenberg, Paweł Rybicki, Jan S. Bystroń) wraz z rozwojem i karierą socjologii jako nauki inspirującej wiele dyscyplin humanistycznych, J. Muszkowski zarysował spójną teorię bibliologiczną, która stała się, z różnymi modyfikacjami, na ponad pół wieku podstawą metodologiczną badań księgoznawczych. Ugruntowana na tradycjach pozytywistycznego spencerowskiego ewolucjonizmu, z ideą rozwoju doskonalącego się „,gatunku” książki (etapy jej badań określał jako „embriologię”, „fizjologię" i „morfologię") oraz jej odbiorców, z priorytetem społecznych uwarunkowań i funkcji, ujęciem systemowym, harmonizowaniem aspektów aksjologicznych i pragmatycznych ${ }^{29}$ — widziana z perspektywy czasu teoria Muszkowskiego ujawnia swój dziewiętnastowieczny rodowód, ale też zaskakuje intuicjami uprzedzającymi późniejsze nurty myśli humanistycznej, np. „dokumentologiczne” — jak wskazano wcześniej — czy „,antropologizujące”. Muszkowski, podobnie jak potem K. Głombiowski, budował humanistyczną wizję bibliologii, dowartościowując zbiorowości kształtujące się w systemie książki, różne rodzaje relacji (role czytelnika, nabywcy, bibliofila, wychowanka, podejmującego samokształcenie, poszukującego informacji, krytyka książki dokonującego jej oceny, wpływającego na postawy i decyzje bibliotekarza itp. ${ }^{30}$. Mimo popularnego języka wywodu, twórca Życia książi dbał o naukową spójność i wyraźne wyznaczenie granic bibliologii jako nauki ${ }^{31}$. Jej metody i narzędzia sięgają jedynie etapu, gdy

27 Małgorzata KOMZA, Mickiewicz ilustrowany, Wrocław: Ossolineum 1987; eadem, Żywe obrazy: między scena, obrazem i ksiązką, Wrocław: Wydaw. Uniwersytetu Wrocławskiego 1995.

28 Jolanta GWIOŹDZIK, Kultura pisma i książki w żeńskich klasztorach dawnej Rzeczypospolitej XVI-XVIII wieku, Katowice: Wydaw. Uniwersytetu Śląskiego 2015.

29 J. MUSZKOWSKI, Życie książki, Kraków: Wiedza — Zawód — Kultura 1951, s. 385-386; idem, Książka jako zjawisko..., s. 79-104; Karol GŁOMBIOWSKI, Nauka o książce w ujęciu Jana Muszkowskiego, Studia o Książce (3) 1972, s. 153-169.

30 ,procesy powstawania, wytwarzania, rozpowszechniania i użytkowania książki dają pole do zjawisk o charakterze społecznym, do faktów społecznych i [...] w przebiegu tych zjawisk tworzą się odrębne grupy społeczne, dla których więzią uświadamianą w większym lub mniejszym stopniu przez członków grupy jest ich stosunek do książki.”, Jan MUSZKOWSKI, Wstęp do socjologii książki, Studia o Książce (3) 1972, s. 97.

31 Muszkowski przyznawał socjologii książki, jako „działowi socjologii”, miejsce nauki pomocniczej księgoznawstwa. 
książka trafia do rąk czytelnika. Dalszymi procesami zajmuje się psychologia („sferą myśli odbiorcy”) oraz historia (,jego czynem”), a także socjologia literatury (publicznością, typami czytelników) ${ }^{32}$. W drugim, powojennym, wydaniu Życia książki „,z duchem czasu” poszerzył obszar dyscypliny o graniczne zagadnienia pedagogiki bibliotecznej oraz światopoglądowego wpływu lektury.

Paradygmat ,życia książki” jako „zespołu faktów społecznych, związanych z powstawaniem, wytwarzaniem i użytkowaniem książki" 33 sprzyjał podejmowaniu — także przez tych, którzy bezpośrednio do teorii Muszkowskiego nie nawiązywali - monograficznych badań instytucji „obsługujących” poszczególne etapy tego życia. Każde z tych pól badawczych wypracowało własne, specjalistyczne metody badań: drukarstwa, ruchu wydawniczego, repertuaru wydawniczego, księgozbiorów itp., modyfikując podstawową metodę historycznej krytyki źródeł oraz ich zespołów. Konsekwencją tej specjalizacji była jednak pewna „defragmentacja" procesu bibliologicznego.

Badacze z perspektywy czasu wskazują na trwałe wartości popularnie ujętej teorii Muszkowskiego: ustalenia i uściślenia terminologiczne — zwłaszcza upowszechnienie nazwy bibliologia, księgoznawstwo; istotny wkład w kształtowanie struktury dyscypliny — bibliologii jako teorii nauki o książce oraz księgoznawstwa, bibliografii, bibliotekoznawstwa jako wewnętrznych subdyscyplin; dowartościowanie aspektów praktycznych, stosowanych; stworzenie teorii, która stała się zarazem podstawą programu kształcenia bibliologicznego; idee „otwartości” oraz interdyscyplinarności nauki o książce; inspiracje informatologiczne.

Trzeba zgodzić się z opinią, że „Dzięki dokonaniom Muszkowskiego bibliologia uzyskała status samodzielnej dyscypliny naukowej i rangę kierunku studiów uniwersyteckich"34. Teoria funkcjonalna K. Głombiowskiego wyraźnie nawiązała do Muszkowskiego w systemowym ujęciu fenomenu książki jako zjawiska kulturowego i społecznego, a zarazem artefaktu o określonym gatunkowo kształcie piśmienniczo-edytorskim z wpisanymi weń a priori i realizowanymi a posteriori funkcjami, ujmowanego procesualnie w całym obiegu i jego instytucjonalnej „obudowie” w kontekście kulturowym i społecznym. Ujęcie Muszkowskiego w pewnym stopniu sprzyjało porządkowi „morfologicznemu”. Głombiowski, stawiając kategorię „funkcji” jako nadrzędną i jednoczącą, zaproponował „odwrócenie kierunku" - wskazał na konieczność integralnego wiązania badań książki z badaniami jej publiczności jako komplementarną perspektywę opisu. Współczesne paradygmaty badawcze w dużej mierze zdezaktualizowały „życie książki” jako kategorię teoretyczną, choć jej elementy są trwale obecne w teorii funkcjonalnej, gdyż w praktyce badawczej jako narzędzie porządkowania materiału

32 J. MUSZKOWSKI, Życie książki..., s. 398-399, 403.

33 J. MUSZKOWSKI, Wstęp do socjologii..., s. 93.

34 J. LADORUCKI, op. cit., s. 43; zob. też zawarte w tym samym tomie teksty Agnieszki Łuszpak i Małgorzaty Komzy. 
bibliologicznego okazała się ona ergonomiczna i elastyczna w przystosowaniu do nowych ujęć. Liczne są więc nadal studia monograficzne wybranych etapów i instytucji obiegu książki, choć sytuowane zwykle w „poszerzonym” semiotyczno-kulturowym lub ,antropologicznym” kontekście.

3. Teoria funkcjonalna Karola Głombiowskiego. Studia poszczególnych instytucji i aspektów procesu bibliologicznego sprzyjały wyodrębnianiu się subdyscyplin, a potem samodzielnych dyscyplin - bibliotekoznawstwa i informacji naukowej, co ponownie wymagało teoretycznego samookreślenia. Zdefiniowania wymagało istotne w myśli Muszkowskiego pojęcie „funkcja książki”. Początkowo wiązano je z treścią książki i jej czytelniczym „wpływem”. Badacze byli świadomi, że bibliologia nie ma po temu wystarczających narzędzi pojęciowych ani warsztatowych, lecz praktyczne potrzeby bibliotekarstwa i pedagogiki bibliotecznej skłaniały do poszerzania zakresu dyscypliny o te aspekty. Już K. Piekarski, a później A. Łysakowski i S. Vrtel-Wierczyński włączali na różny sposób zagadnienia graniczne (socjologiczne, psychologiczne, literackie) w zakres i strukturę pojęciową bibliologii 35 .

Próbę opracowania teorii $\mathrm{w}$ jednolitym „schemacie pojęciowym nauki o książce"36, której podstawę stanowi trójdzielny, lecz integralny proces bibliologiczny, podjął w latach 60 . i później K. Głombiowski ${ }^{37}$. Książka, czyli „tekst zmaterializowany w fizycznej strukturze książki”38, w jedności treści i formy edytorskiej, była dla niego gatunkiem kulturowej, społecznej komunikacji, nieredukowalnym do funkcji nośnika treści. Kategorię funkcji rozumiał wieloaspektowo: funkcję formy wydawniczej książki wobec tekstu dzieła, funkcje systemu książki i jego instytucji w procesie komunikowania, a wreszcie funkcje społeczne piśmiennictwa, aby zapewnić „utrzymanie, integrację i historyczną ciągłość społeczeństwa" ${ }^{39}$. Istotą struktury książki jest komunikatywność (na poziomie rzeczowym i semiotycznym), czyli „dostępność dla zdolności percepcyjnych czytelnika, osiągana za pomocą środków komunikacyjnych właściwych ekspre-

35 Vrtel-Wierczyński konsumpcję książki lokował w swojej teorii bibliologii w trzech poddziałach: czytelnictwo, socjologia książki i psychologia bibliologiczna, zob. S. VRTEL-WIERCZYŃSKI, Teoria bibliografii..., s. 206-207, 210-211.

${ }^{36}$ K. MIGOŃ, Historia czytelnictwa wedtug Karola Głombiowskiego, Rocznik Gdański (61) 2001, z. 2, s. 9-18.

37 K. GŁOMBIOWSKI, Teoria i metodologia nauki o książce, Gdańsk: Wydaw. Uniwersytetu Gdańskiego 1985; idem, Książka w procesie komunikacji społecznej, Wrocław [i in.]: Zakład Narod. im. Ossolińskich 1980; K. MIGOŃ, Karol Głombiowski (1913-1986), Studia o Książce (17) 1988, s. 3-14; B. KOREDCZUK, Karol Głombiowski - twórca wrocławskiej szkoły bibliologicznej, [w:] Książka i biblioteka w procesie komunikacji społecznej. Pod red. Renaty Aleksandrowicz i Haliny Rusińskiej-Giertych, Wrocław: Oficyna Wydaw. Atut 2015, s. 19-38.

38 K. GŁOMBIOWSKI, $O$ dwóch tendencjach badań bibliologicznych, Studia o Książce (11) 1981, s. 12-13.

39 K. GŁOMBIOWSKI, O funkcjonalna teorię nauki o książce, Studia o Książce (1) 1970, s. 24.

Roczniki Biblioteczne 60, 2016

(C) for this edition by CNS 
sji książkowej’40. Teorię funkcjonalną Głombiowski wyraźnie odróżniał od tych koncepcji, które definiując książkę jako jeden z tekstów kultury, pozbawiają ją bibliologicznej differentia specifica, autonomicznej tożsamości ${ }^{41}$.

Teoria Głombiowskiego wielu pracom badawczym w kraju i za granicą dała metodologiczny fundament:

ich przedmiotem jest dawna (w mniejszym stopniu współczesna) kultura książki; książka rozumiana jest jako społeczne narzędzie komunikacji, a fakty bibliologiczne są objaśniane na gruncie wiedzy o funkcjonalnych właściwościach książki, w wielorakich kontekstach jej bytowania; perspektywa badawcza obejmuje rozległy obszar problemów od wytwarzania książek po ich odbiór (a więc cały „proces bibliologiczny”) ${ }^{42}$.

Stała się podstawą wrocławskiej szkoły badań bibliologicznych, zwłaszcza w zakresie teorii księgoznawstwa, historiografii książki oraz historycznych badań bibliotek i czytelnictwa.

U Głombiowskiego znaleźć można inspiracje, które nieco później pojawiły się w literaturoznawstwie i upowszechniły w bibliologii: przekonanie o znaczeniu edytorskich elementów eskortujących dla kulturowej recepcji tekstu sprzyjało rozwojowi badań literackiej ramy wydawniczej, a dokumentowanie, że „Każdy składnik morfologiczny książki jest w zasadzie obciążony znaczeniem" "43, inspirowało do refleksji nad semiotyką i funkcjonalnością książki, co podjęli później R. Cybulski i Teodor Zbierski. Istotne było rozumienie repertuaru, jednej z podstawowych kategorii poznawczych w bibliologii (bibliotecznego, instytucjonalnego, grupowego, indywidualnego), jako zasobu danych dokumentujących funkcjonowanie książki, odsłaniających sens lekturowych decyzji, a nawet wzory lekturowych norm i praktyk, szukającej odpowiedzi na pytanie „w jakiej mierze produkcja wydawnicza danej formacji historycznej wpływa przy pomocy swego repertuaru na ukształtowanie świadomości czytelników w jej podstawowych elementach"44. Głombiowski otwierał drogę refleksji nad podmiotowymi działaniami samych odbiorców jako twórców, przeobrazicieli i obiorców świata książki, a więc dla perspektywy sensu largo antropologicznej: „chciał dotrzeć do człowieka, jego działania i życia wewnętrznego ujawniającego się w tworzeniu,

${ }^{40}$ K. GŁOMBIOWSKI, $O$ dwóch tendencjach..., s. 9. „Zamykał” więc granice dyscypliny „nieksiążkowym” przekazom piśmienniczym, jak np. mikrofilmy.

${ }^{41}$ Głombiowski świadomie unikał kategorii „tekstu kultury” zdobywającej wówczas miejsce w humanistyce. Świadczą o tym jego polemiki z oponentami, w których formułował swoje obawy i wyjaśniał powody odrębności stanowiska. Zob. J. KOSTECKI, W okopach bibliologii, w okowach bibliofilstwa. Cz. 1-2, Bibliotekarz 1981, nr 2, s. 44-47; nr 3, s. 70-74; K. GŁOMBIOWSKI, Czy bibliologia może się wybić na samodzielność? (W odpowiedzi moim czytelnikom - rzeczywistym i urojonym), Roczniki Biblioteczne (27) 1983, z. 1-2, s. 559-605.

42 K. MIGOŃ, Bibliologia historyczna..., s. 50.

${ }^{43}$ K. GŁOMBIOWSKI, Ksiażka a inne sposoby zapisu dzieła piśmienniczego, czyli o semiotyce książki, Studia o Książce (13) 1983, s. 8.

44 K. GŁOMBIOWSKI, Problemy historii czytelnictwa, Wrocław: Zakład Narod. im. Ossolińskich 1966, s. 8. 
gromadzeniu, opisywaniu, czytaniu książek”45. Postulując „empiryczną i teoretyczną rozbudowę aspektu socjologicznego", definiując stanowisko funkcjonalne jako „odniesienie roli książki do całości życia społecznego”, pytając „, jakich zbiorowościach społecznych książka działa i jakim potrzebom kulturalnym tych zbiorowości odpowiada" "46, sprzeciwiał się zarazem zawężaniu badań bibliologicznych do zagadnień odbioru i czytelnictwa. Miał świadomość, że tworzy model dyskursywny, którego „,idealnie” ujęte założenia zweryfikują badania empirycz$\mathrm{ne}^{47}$. Teoria Głombiowskiego przyczyniła się niewątpliwie do „wybicia się bibliologii na niepodległość", do uznania odrębności (choć nie braku pokrewieństw) z innymi dyscyplinami, zwłaszcza literaturoznawstwem: „,bibliolog patrzy szerzej: istotna jest dla niego nie treść dzieła, lecz treść książki, a więc tekst główny w powiązaniu z wszelkimi elementami jego książkowej materializacji”"48. Opinię, iż Głombiowski „postawił nieobecne przedtem w literaturze pytania, podjął tematy, których wartości dotąd nie doceniono, [...] wzbogacił swoimi pracami nie tylko znajomość historycznych procesów, lecz także pokazał drogę dalszego postępowania badawczego"49, odnieść można nie tylko do jego prac nad historią kultury książki na Śląsku.

Ujęcia „systemowe" $i$ „,funkcjonalne” stały się w księgoznawstwie powszechnie przyjętym założeniem metodologicznym, znajdując w pracach K. Migonia wszechstronną teoretyczną wykładnię i międzynarodowe konteksty: „Obiektem księgoznawstwa jest książka i procesy bibliologiczne: tworzenie, obieg i odbiór książki, a także skutki tych procesów oraz ludzie i instytucje w nich uczestniczące. Tak określony obiekt można by w skrócie sprowadzić do formuły książkaczytelnik" ${ }^{\prime 50}$. Dostrzegano podmiotową rolę odbiorcy, lecz za główny przedmiot badań uznawano nadal książkę w „bogactwie i wzajemnych związkach formy,

45 K. MIGOŃ, Karol Gtombiowski (1913-1986)..., s. 11; Karol GŁOMBIOWSKI, Nauka o książce nauka o człowieku, Studia o Książce (4) 1973, s. 26-40. Podobnie — zarówno jako komentowanie, przeobrażanie i tworzenie — definiował uczestnictwo w kulturze Andrzej TYSZKA, Uczestnictwo w kulturze. O różnorodności stylów życia, Warszawa: PWN 1971.

${ }^{46}$ K. GŁOMBIOWSKI, O funkcjonalna koncepcję nauki o książce, Studia o Książce (1) 1970, s. 8-9.

47 Nie zawsze zwracano uwagę na istotne w wizji Głombiowskiego aspekty moralne i estetyczne zarazem, zakorzenione w ideałach greckiej „kalokagatii”. W odniesieniu do funkcji książki widział to Stanisław Antoni KONDEK, Organizacja obiegu książek w PRL jako eksperyment bibliologiczny, [w:] Bibliologia..., s. 325.

48 Por. Agnieszka BORYSOWSKA, Bibliologia a literaturoznawstwo - pokrewieństwo warsztatów historyka ksiązki i historyka literatury, [w:] Bibliologia. Problemy badawcze..., s. 86.

49 K. MIGOŃ, Bibliologia historyczna..., s. 51.

50 K. MIGOŃ, Nauka o książce. Zarys..., s. 108-109. Wówczas autor za główny obiekt badań uznawał książkę jako specyficzne zjawisko kulturowe, a nie dokument piśmienniczy, ku czemu przychylił się później. 
treści i funkcji”51, ujmowaną dynamicznie, choć nierzadko w sposób nieco „antropomorfizujący". Badacze rzadziej obejmowali całość procesu bibliologicznego, co było możliwe w odniesieniu do mniejszych środowisk czy ograniczonych czasokresów $^{52}$. Dokumentując jednak wybrane podsystemy, np. księgarstwo, repertuar i recepcję książki orientalnej, powieści osiemnastowiecznej, edytorskie losy elementarza czy podręcznika ${ }^{53}$, interpretowano je w ujęciu procesualnym i funkcjonalnym ${ }^{54}$.

Będąca dla K. Głombiowskiego warunkiem istnienia szkoły naukowej „trwałość wspólnoty podstawowych poglądów i metod badawczych" 55 - już sześćdziesięcioletnia $\mathrm{w}$ odniesieniu do zasadniczych założeń teorii funkcjonalnej — potwierdziła żywotność tej teorii jako fundamentalnej dla polskiego księgoznawstwa, nie tylko historycznego, choć oczywiście nadal podlegającej rozwojowi ${ }^{56}$.

4. Janusz Dunin - badacz edytorskich postaci książki powiązał bibliologiczną tradycję źródłowych, historycznych badań nad książką z teorią

51 Tak określiła przedmiot badań K. Bednarska-Ruszajowa w recenzji drugiego wydania książki K. Migonia (Studia o Książce (17) 1988, s. 388).

${ }^{5}$ Np. Iwona IMAŃSKA, Obieg książki w Prusach Królewskich w XVIII w., Toruń: Wydaw. UMK 1993; eadem, Druk jako wielofunkcyjny środek przekazu w czasach saskich, Toruń: Wydaw. UMK 2000.

53 Elżbieta SŁODKOWSKA, Produkcja i rozprowadzanie wydawnictw w Królestwie Polskim w latach 1815-1830, Warszawa: Biblioteka Narodowa 2003; K. MIGOŃ, Recepcja książki orientalistycznej na Śląsku do końca XVIII wieku, Monografie z Dziejów Nauki i Techniki (62), Wrocław 1969; Elżbieta ZAWISZA, Powieść w kulturze czytelniczej Francji XVIII wieku, Wrocław: Wydaw. Uniwersytetu. Wrocławskiego 1993; Franciszek PILARCZYK, Elementarze polskie od ich XVI-wiecznych początków do II wojny światowej: próba monografii księgoznawczej, Zielona Góra: Oficyna Wydawnicza Uniwersytetu Zielonogórskiego 2003.

54 Ujęcie funkcjonalne właściwe było wówczas także literaturoznawstwu. Np.: „Za »życie literackie« trzeba by wówczas uważać zbiór funkcji literatury wraz z obsługującymi te funkcje instytucjami. Badania winny obejmować podstawowy repertuar funkcji literatury i zająć się instytucjonalnym urzeczywistnieniem tych funkcji. [...] Badanie mechanizmów obsługiwania określonych funkcji byłoby więc podstawowym zadaniem badacza życia literackiego" (Krzysztof DMITRUK, Literatura, społeczeństwo, przestrzeń. Przemiany układu kultury literackiej, Wrocław [i in.]: Ossolineum 1980, s. 15-16).

55 K. GŁOMBIOWSKI, Moja droga ku nauce o książe. Cyt. za: K. MIGOŃ, Bibliologia historyczna..., s. 55.

56 Centralna w bibliologii kategoria funkcji była jednak przedmiotem niewielu studiów teoretycznych. Oprócz prac K. Głombiowskiego można wymienić m.in.: J. KOSTECKI, Pojęcie funkcji w bibliotekoznawstwie, Bibliotekarz (45) 1979, nr 5, s. 121-124; nr 6, s. 148-151; Jerzy WŁODARCZYK, Funkcja społeczna książki. Z problematyki metod badawczych, Acta Universitatis Lodzensis Folia Librorum (3) 1992, s. 29-49; Irena SOCHA, O pojęciu funkcji w bibliologii, [w:] Studia i rozprawy bibliologiczne. Pod red. Krystyny Heskiej-Kwaśniewicz, Katarzyny Tałuć, Katowice: Uniwersytet Śląski 2012, s. 101-110. 
funkcjonalną i perspektywą „,komunikacyjną" ${ }^{257}$. Książka ma naturę dialogową nie tylko dlatego, że służy społecznej komunikacji jako przekaźnik treści, lecz przede wszystkim dlatego, że jest „zapisem” określonej sytuacji kulturowej i społecznej (także rynkowej), a zarazem nośnikiem potencji społecznego dialogu, ekonomicznej konsumpcji, rzeczowego i intelektualnego spożytkowania. Komunikacja ta dokonuje się poprzez określony kształt piśmienniczo-wydawniczy, właściwe mu cechy strukturalne i funkcje modyfikowane przez odbiorcę w określonych sytuacjach $^{58}$. Dunin realizował wizję bibliologii jako nauki dysponującej specjalistycznym warsztatem i jasno sprecyzowanym przedmiotem badań, lecz zarazem otwartej, inspirowanej teorią nauk o kulturze i literaturze oraz humanistycznie zorientowaną socjologią. Był świadomy, że bibliologia może być tym bardziej „otwarta”, tym bardziej interdyscyplinarna (co nie znaczy eklektyczna), im bardziej jest świadoma swojej tradycji, specyfiki swojego pola badawczego i warsztatu. Dunin był jednym z pierwszych badaczy książki w otoczeniu jej edytorskich i komunikacyjnych paratekstów ${ }^{59}$. W latach 80 ., a zwłaszcza 90., studia literackiej ramy wydawniczej, elementów ,eskortujących” (dedykacje, wiersze do czytelnika, tekst ilustracji, okładki itp.) dowartościowanych jako konstytutywne, istotne dla odbioru i społecznych funkcji tekstu rozwijały się już bujnie na gruncie literaturoznawstwa. Bliska była Duninowi teza Głombiowskiego, że nauka o książce (zwłaszcza historyczna) jest nauką o człowieku. Jako badacz historii lektury poszukiwał zwłaszcza „,antropologicznych” aspektów komunikacji różnicujących kulturowe wspólnoty. Może dlatego chętnie badał zjawiska osobliwe (książka jarmarczna, brukowa, dziecięca) oraz ich odbiorców o specyficznym charakterze czytelniczych decyzji i opinii?

5. Konsumpcja książki w ujęciu Radosława Cybulskiego. Teoria książki kształtowała się początkowo głównie na materiale prac historycznych. W odniesieniu do współczesnego zasobu druków rozwinął ją Cybulski, łącząc dobrze już ugruntowane pojęcia dotyczące morfologii książki z perspektywą semiotyczną. Powrócił do kategorii „konsumpcji książki”, przyjętej przez Muszkowskiego, potem rzadko używanej, która okazała się funkcjonalna w obserwacji zachowań uczestników rynku książki (czytelniczych, księgarskich, klubowych

57 J. DUNIN, Rozwój cech wydawniczych polskiej ksiązki literackiej XIX-XX wieku, Łódź: Uniwersytet Łódzki 1982; Pasja książki. Studia poświęcone pamięci profesora Janusza Dunina. Pod red. Jacka Ladoruckiego i Małgorzaty Rzadkowolskiej, Łódź: Wydaw. Literatura 2009.

58 J. Dunin doceniał rzeczowe aspekty ergonomii i funkcjonalności edytorskiej postaci książki. Jednym z tego wyrazów były pomysły takie jak „WC Book. Książka klozetowa dla rozweselenia i refleksji” — żart wydawniczy, który miał też „poważniejszą” rolę: uświadomienie funkcji książki jako jedności jej tekstu, szaty edytorskiej i sposobu „użycia” w określonej sytuacji.

59 K. Migoń podaje 1979 rok jako termin zakończenia dzieła Rozwój cech wydawniczych polskiej ksiązki literackiej XIX-XX wieku (idem, Teoria ksiązki w ujęciu Janusza Dunina, [w:] Pasja ksiązki..., s. 18). 
itp. ${ }^{60}$. Sięgając do inspiracji myśli socjologicznej Jana Szczepańskiego, zmodyfikował ją, czyniąc przedmiotem badań nie tylko konsumenckie zachowania i postawy jednostek czy grup, lecz także ,zintegrowany system zaspokojenia potrzeb użytkowników książek" "61. Istotnym problemem było zorganizowanie i funkcjonowanie tego systemu, a także więzi tworzące się w jego ramach oraz bariery powodujące jego dysfunkcję. Przezwyciężał tym samym podatność na „defragmentację" badań procesu bibliologicznego, jakiej w pewnej mierze sprzyjała kategoria „życia książki”. Nowa u Cybulskiego-teoretyka była redefinicja książki jako struktury semiotycznej i komunikacyjnej, jej powiązanie z funkcjonowaniem całego systemu książki. Zakładał, że w wielowarstwowej strukturze morfologicznej i funkcjonalnej książki, w jej „porządkach” wewnętrznych (edytorskich elementach składowych pełniących określone funkcje w odbiorze) są zakodowane procesy obiegu, społecznego użytkowania, konsumpcji, a także ich społeczne i kulturowe konteksty. Było to zintegrowane spojrzenie na system komunikacyjny książki - informacyjny, lecz także społeczny, ekonomiczny, technologiczny, estetyczny. Dla Cybulskiego, podobnie jak dla poprzedników, istotna była perspektywa humanistyczna: system książki jako rzeczywistość ekonomiczną i organizacyjną, a w nim zachowania i wybory konsumenckie, łączył ściśle z problemem społecznych więzi i stylem życia użytkowników oraz jego aksjologicznym fundamentem - waloryzowaniem dóbr kultury (sieć wartości, teoria motywów, teoria struktur poznawczych). Cybulski nie przenosił teorii i kategorii myślowych nauk społecznych i ekonomicznych ani psychologii na grunt nauki o książce, lecz na gruncie bibliologii integrował te perspektywy opisu, tworząc spójną konceptualnie bibliologiczną teorię konsumpcji książki i zarazem procedurę badawczą możliwą do zastosowania w praktyce. Dawał funkcjonalne narzędzie zarówno badaczom zjawisk historycznych, jak i współczesnych, wydawniczych i bibliotekarskich - księgarskich oraz czytelniczych.

Refleksje nad semiotyką książki kontynuował T. Zbierski ${ }^{62}$. Pojawiały się one także u K. Głombiowskiego, dla którego książka była przedmiotem semiotycznym we współdziałaniu znaczeń tekstu, pisma oraz ekspresji „,materii” książki w służbie komunikatywności przekazu ${ }^{63}$. Dla bibliologów jednak „myślenie semiotyczne" nie stało się, jak np. w literaturoznawstwie czy naukach o kulturze, podstawą zasadniczego „zwrotu” - całkowicie nowych teorii i kierunków badań oraz aparatu pojęciowego. Raczej, świadomi stabilności i funkcjonalności wypracowanego już fundamentu metodologicznego oraz warsztatu pojęciowo-operacyjnego, wy-

60 R. CYBULSKI, Struktura i właściwości książki..., s. 3-38; idem, Książka współczesna. Wydawcy - rynek - odbiorcy, Warszawa: PWN 1986.

61 R. CYBULSKI, Konsumpcja książki. Zarys problematyki, Roczniki Biblioteczne (17) 1983, z. $1 / 2$, s. 457.

62 Teodor ZBIERSKI, Semiotyka książki, Wrocław: Ossolineum 1978.

63 K. GŁOMBIOWSKI, Książka a inne sposoby zapisu...; idem, O dwóch tendencjach badań... 
korzystywali kategorie semiotyczne do pogłębienia metodologicznego status quo. Dla Zbierskiego inspiracje te stały się podstawą definiowania książki jako struktury komunikacyjnej waloryzowanej przez kryterium funkcjonalności i ergonomii, lecz na fundamencie już istniejących morfologicznych jej wyznaczników, a dla Głombiowskiego - argumentem potwierdzającym funkcjonalną koncepcję.

Propozycje nowe, zasadniczo zmieniające teoretyczną wizję księgoznawstwa, wychodziły częściej spoza środowiska bibliologicznego. Jan Pomorski nową lokalizację bibliologii, a tym samym jej struktury, widział w obszarze nauk o społecznym komunikowaniu ${ }^{64}$. Do transformacji, która kazałaby niejako na nowo budować metodologiczną tożsamość bibliologii w ramach większej całości, nie doszło. Natomiast dyskusje wokół przedmiotu księgoznawstwa przyczyniły się do wyodrębniania informologii jako osobnej dyscypliny. Perspektywa semiotyczna okazała się ważna również dla badania elektronicznych postaci książki. Małgorzata Góralska odwołuje się do inspiracji Cybulskiego i pojęcia książki funkcjonalnej, lecz przede wszystkim do semiotycznego instrumentarium (kodów semantycznych) Umberta Eco, zauważając, iż „odejście od kodów komunikacji piśmienniczej na rzecz technologii komputerowej” powoduje również zmiany funkcji65.

6. Kariera społecznej sytuacji komunikacyjnej jako kategorii i perspektywy badawczej była jedną z konsekwencji socjologicznej i semiotycznej reorientacji myślenia humanistycznego, a z czasem okazała się podatna dla rozwoju ujęć ,antropologizujących”. W bibliologii miała swój rodowód i umocowanie w komunikacyjnie i socjologicznie zorientowanej teorii funkcjonalnej, włączona w porządek triadycznego procesu bibliologicznego ${ }^{66}$, lecz do jej spopularyzowania, pewnego nawet usamodzielnienia, przyczyniły się prace socjologów literatury, m.in. eseistycznie ujęte, popularne w Polsce od połowy lat 60. teksty Roberta Escarpita $^{67}$, a w humanistyce polskiej szkoła badawcza Stefana Żółkiewskiego. Podobnie jak w nauce o literaturze, gdy w latach 70. i 80. pojęcie „,̇ycia literackiego" sytuowane w strukturze procesu historycznoliterackiego, badacze zorientowani na socjologię literatury (S. Żółkiewski, K. Dmitruk, J. Lalewicz) zastępowali kategorią „,sytuacja komunikacyjna”, tak też w bibliologii pojawiła się ona w miejsce tradycyjnego ,życia książki”, bliska teorii funkcjonalnej, której twórca sprzeciwiał się jednak stawianiu czytelnika, jako obiektu badań, na miejsce książki ${ }^{68}$.

64 Jan POMORSKI, $W$ kierunku teoretycznej integracji badań bibliologicznych, Studia o Książce (15) 1985, s. 157-189; idem, Teoria i bibliologia. W kierunku teoretycznej integracji badań bibliologicznych, [w:] Profile nauki o książce. Red. J. Pomorski, Lublin: UMCS 1988, s. 7-42.

${ }^{65}$ M. GÓRALSKA, Funkcjonalność oraz komunikatywność ksiażki tradycyjnej i elektronicznej w perspektywie semiotycznej, [w:] Bibliologia. Problemy badawcze..., s. 360-370.

66 Por. Jerzy W. ZAWISZA, Propozycja schematu komunikacji bibliologicznej, Studia o Książce (10) 1980, s. 39-57.

67 Por. Janusz ANKUDOWICZ, Roberta Escarpita koncepcja socjologii książki, Studia o Książce (3) 1972, s. 267-277.

68 K. GŁOMBIOWSKI, $O$ dwóch tendencjach badań..., zwłaszcza s. 13. 
Podstawy teoretyczne i zarazem model badań empirycznych, łącząc kategorie literaturoznawcze $\mathrm{z}$ warsztatem bibliologicznym, dał J. Kostecki na przykładzie analizy społecznych sytuacji komunikacji czytelniczej oraz właściwych im społecznych funkcji tekstu drugiej połowy XIX wieku, rekonstruowanych na podstawie świadectw pamiętnikarskich ${ }^{69}$. Przyjmował — za Stefanem Żółkiewskim — iż „,w kształtowaniu zachowań czytelniczych szczególną rolę sterującą pełnią instytucje społeczne"70. Źródłem wyjaśnień stały się ,różnorodne przymusy kulturowe", które pokazują siłę i sposób oddziaływania insty tucji, możliwość dostępu do tekstów i sposoby odczytań. Proces komunikacji czytelniczej widział Kostecki jako trójwymiarowe relacje między: ,zespołem instytucji związanych z produkcją, upowszechnianiem i udostępnianiem tekstów”, „obiektywnie dostępnym zbiorem tekstów”, ,publicznością czytelniczą”. Najpełniej zależności te ukazał na podstawie bogatego i różnorodnego zasobu źródeł, badając cenzurę drugiej połowy XIX wieku nie tylko jako instytucję sensu stricto kontroli od strony jej zorganizowania i funkcjonowania, lecz także jako sui generis system komunikacyjny warunkujący działanie całego obiegu książki, dostępne repertuary i ich odbiór oraz kryteria wartościowania ${ }^{71}$. Kostecki dowartościował czynniki „osobowościowe" $i$ aspekty aksjologiczne, rolę publiczności, która nadawała danej sytuacji oryginalny wyraz, czego ujawnienie było możliwe także dzięki odwoływaniu się do dokumentów biograficznych ${ }^{72}$.

Podobna orientacja teoretyczna oraz zespół źródeł (pamiętniki) znalazła swoją syntezę w pracy Stanisława Siekierskiego, wyróżniającego główne sytuacje komunikacji czytelniczej końca XIX i pierwszej połowy XX wieku z właściwymi im sposobami czytania, społecznym i kulturowym statusem książki, lecz także zorganizowaniem formalnym i nieformalnym ${ }^{73}$. Wyróżnikiem sytuacji komunikacyjnej był dla niego przede wszystkim „sposób czytania”, a więc lekturowe decyzje i zachowania określonych społeczności realizujących własne kulturowe cele, a wyróżnikiem drugorzędnym sposób zorganizowania.

Szeroko rozumiana kategoria „sytuacji komunikacyjnej”, w większym stopniu niż „życie książki” (ukierunkowane raczej na opis aspektów formalnych i organizacyjno-instytucjonalnych) uwzględniająca aspekty aksjologiczne związane z wartościującymi decyzjami uczestników, okazała się interesująca dla młodszych pokoleń bibliologów i zaskakująco bogata w wielorakich realizacjach. Jako cie-

69 J. KOSTECKI, Charakterystyka wybranych..., passim.

70 Ibidem, s. 53

71 J. KOSTECKI, Trudny proces przenikania. Carska cenzura zagraniczna wobec importu publikacji w języku polskim w latach 1865-1904, Warszawa: Biblioteka Narodowa 2011.

72 J. KOSTECKI, Czytelnik w świecie wartości, [w:] Dokument, książka i biblioteka w badaniach naukowych i nauczaniu uniwersyteckim. Pod red. Marty Skalskiej-Zlat i Anny Żbikowskiej-Migoń, Wrocław: Wydaw. Uniwersytetu Wrocławskiego 2008, s. 85-113.

${ }^{73}$ Stanisław SIEKIERSKI, Czytania Polaków w XX wieku, Warszawa: Wydaw. Uniwersytetu Warszawskiego 2000. 
kawy kierunek ujawniła się „bibliologia polityczna”74 — studia otwierające perspektywę na ideologiczne konteksty funkcjonowania systemu książki i czytelnictwa. Monografie Stanisława Adama Kondka rzetelnie dokumentowały meandry organizacyjno-prawne, instytucjonalne i publicystyczne funkcjonowania książki w latach ideologizacji życia społecznego i kulturalnego $1945-1956^{75}$. Prace Andrzeja Dróżdża ukazywały ideologiczne uwikłania i role książki w historii kultu$\mathrm{ry}^{76}$. Liczne studia i monografie diagnozowały sytuacje kulturowej komunikacji poprzez związek z instytucją opiniotwórczą, np. Kościołem (Małgorzata Rzadkowolska, Jerzy Plis, Bogumiła Warząchowska), prasą (Jerzy Franke, Agnieszka Paja, Anna Zdanowicz), partią polityczną, ideologią (Danuta Adamczykowa, Oskar Czarnik), z sytuacją społeczną (Maria Krisań) czy edukacyjno-wychowawczą (A. Zdanowicz, Anna Nosek) ${ }^{77}$. Studia te docierały do tego wyróżnika sytuacji komunikacyjnej i związanej z nią instytucji, jakim była specyficzna jakość aksjologiczna - sposób waloryzowania książek, konstytuowania repertuarów i norm czytania, kształtowania opinii. Wartością ujęć bibliologicznych było dokumentowanie, jak dla celów polityki i ideologii funkcjonuje system książki i prasy, różne instytucje i środowiska stanowiące jego organizacyjno-materialną podstawę ${ }^{78}$.

7. Książka w przestrzeni medialnej. Na znaczenie medialnego kontekstu masowej kultury, istotnego dla odbioru publikacji, zwracali uwagę socjologowie kultury (nawiązując do głośnych w latach 70. lektur Herberta M. McLuhana, R. Escarpita, Edgara Morina, Gillo Dorflesa, U. Eco): Marcin Czerwiński, Antonina Kłoskowska, Alicja Rokuszewska-Pawełek, Katarzyna $\mathrm{Citko}^{79}$ oraz

${ }^{74}$ Za prekursora teoretycznych podstaw tej orientacji myślowej K. Migoń uznaje R. Estivalsa, a za pierwszego badacza podążającego w tym kierunku - H.-J. Martina, autora pracy Livre, pouvoirs et société à Paris au XVIIe siècle (1598-1701) (t. 1-2, Genève 1969). Zob. K. MIGOŃ, Bibliologia wśród innych nauk..., s. 23.

75 S.A. KONDEK, Władza i wydawcy. Polityczne uwarunkowania produkcji ksiażek w Polsce w latach 1944-1949, Warszawa: Biblioteka Narodowa 1993; idem, Papierowa rewolucja. Oficjalny obieg ksiażek w Polsce w latach 1948-1955, Warszawa: Biblioteka Narodowa 1999.

76 Andrzej DRÓŻDŻ, Książki i rewolucja: ks. Antonio Marini-neapolitański jakobin i jego biblioteka, Kraków: Wydaw. Nauk. Akad. Pedagogicznej 2004; idem, Od liber mundi do hipertekstu: ksiażka w świecie utopii. Wyd. 2 popr. i uzup., Warszawa: Biblioteka Analiz 2009.

77 Te prace bibliograficznie wykazano w: I. SOCHA, Zachowania lekturowe Polaków problemy i kategorie opisu czytelnictwa, [w:] Teoretyczne zagadnienia bibliologii i informatologii. Studia i szkice. Pod red. Elżbiety Gondek, Katowice: Wydaw. Uniwersytetu Śląskiego 2015, s. 11-30.

78 Np. Oskar S. CZARNIK, Ideowe i literackie wybory „,Robotnika” w latach 1918-1939, Warszawa: Biblioteka Narodowa 1996; Danuta ADAMCZYK, Wydawnicza i kulturotwórcza dziatalność spółki nakładowej „Książka” 1904-1914 : z dziejów wydawnictw PPS, Warszawa-Kraków: PWN 1988; eadem, Instytucje wydawnicze Polskiej Partii Socjalistycznej 1892/1893-1948, Kielce: WSP im. Jana Kochanowskiego 1997.

79 Marcin CZERWIŃSKI, System ksią̇ki, Warszawa: WAiF 1976, zwłaszcza s. 5-67; Antonina KŁOSKOWSKA, Potoczny odbiór i funkcje literatury, [w:] Mimesis w literaturze, kulturze i sztuce. Pod red. Z. Mitosek, Warszawa 1992, s. 215-227; A. KŁOSKOWSKA, Alicja ROKU- 
badacze czytelnictwa ${ }^{80}$. Pojawiły się próby wpisania bibliologii jako subdyscypliny, obok prasoznawstwa, w zakres metanauki o masowym komunikowaniu ${ }^{81}$. W bibliologii rozumienie książki jako fenomenu ze swej natury „komunikacyjnego" kształtowało się już w latach 30., a potem Głombiowski, a zwłaszcza Dunin, przyczynili się do spopularyzowania i rozwoju tych koncepcji ${ }^{82}$. Wyzwania pojawiające się przed bibliologią $\mathrm{W}$ związku z rozwijającym się dynamicznie, zwłaszcza na gruncie nauk o kulturze i socjologii, lecz jeszcze nie w pełni teoretycznie ukształtowanym medioznawstwem, podsumował K. Migoń, stawiając pytania o perspektywy współistnienia ${ }^{83}$. Odnotowując wzbogacenie badań bibliologicznych dzięki inspirującej perspektywie medioznawczej, wskazuje na odmienny obiekt badań — gdy w bibliologii jest to książka lub, szerzej, dokument piśmienniczy, w medioznawstwie są to środki przekazu, przy czym skupia ono uwagę głównie na tych, które uczestniczą w komunikacji masowej.

Perspektywę badawczą wynikającą z rozpoznania intermedialności współczesnej kultury, łączącą oba pola problemowe - księgo- i medioznawcze - zaproponowali w ostatnich latach przedstawiciele młodego pokolenia bibliologów: Małgorzata Góralska, Anita Has-Tokarz i Michał Rogoż. Nowe, polimorficzne postacie komunikatów funkcjonujących jako popkulturowe produkty totalne przeobrażają strukturę i funkcje tradycyjnej książki, jej cechy gatunkowe oraz związek z określoną sytuacją odbiorczą. Każe to badaczom poszerzyć pole obserwacji na inne komunikaty, obok niej współistniejące w kulturze: filmowe, audialne, sieciowe (internetowe) i komputerowe, komiksowe i prasowe, które choć przekazują podobne treści, są często preferowane ze względu na ergonomię, potencjał emocji, szybkość transmisji, łatwość odbioru. Ma to szczególne znaczenie w odniesieniu do książek dziecięcych poddawanych powszechnie procesowi „totalizacji” produktu, zastępowania oryginałów adaptacjami i przeróbkami ${ }^{84}$.

SZEWSKA-PAWEŁEK, Mity literackie w świadomości potocznej, Kultura i Społeczeństwo (21) 1977, s. 35-62; Katarzyna CITKO, Sytuacja odbiorcy $w$ dobie ekspansji nowych mediów, [w:] Kultura i sztuka u progu XXI wieku. Red. Sław Krzemień-Ojak, Białystok: „Trans Humana” 1997, s. 283-291.

80 R. CHYMKOWSKI, Czytanie z ekranu..., s. 109-122; Katarzyna WOLFF, Wspótczesny czytelnik - między mediatyzacją a indywidualizacją. Kilka refleksji o wspólnocie narracji lekturowych i ich głównych mechanizmach, [w:] Czytanie, czytelnictwo, czytelnik. Red. Anna Żbikowska-Migoń przy współudz. Agnieszki Łuszpak, Wrocław 2011, s. 101-117.

81 Zob. przypis 68. Polemizowała z tym stanowiskiem K. BEDNARSKA-RUSZAJOWA, Z teorii i metodologii księgoznawstwa oraz dyscyplin pokrewnych 1987-1990, Studia o Książce (19) 1993, s. 190.

82 Np. J. DUNIN, Czasopisma i książki w świecie mediów XXI wieku, [w:] Media studies. Refleksja nad stanem obecnym. Red. Maciej Rajewski, Krzysztof Stępnik, Lublin: UMCS 2008, s. $227-234$.

${ }^{83}$ K. MIGOŃ, Bibliologia wobec medioznawstwa ..., s. 13-18.

84 Michał ZAJĄC, Promocja książki dziecięcej, Warszawa: SBP 2000; idem, Książka dla dzieci i młodzieży jako przedmiot badań bibliologicznych. Zarys problematyki, [w:] Bibliologia, biblioteki, bibliotekarze. Praca zbior. pod red. Dariusza Grygrowskiego i Elżbiety Barbary Zybert, 
M. Góralska, dostrzegając problem współistnienia książki „we współczesnej rzeczywistości komunikacyjnej, na którą składają się różnorodne systemy medialne", przyjmuje za punkt wyjścia kategorie czasu i przestrzeni. W tym wymiarze dostrzega nowe funkcje książki: jako „swoiste antidotum na zawrotny dynamizm nowych mediów, jako szansę spowolnienia komunikacji, gwarancję zachowania »wartości ponadczasowych « ${ }^{85}$. A. Has-Tokarz i M. Rogoż na różnych materiałach badawczych - horrorów i fantastyki jako gatunku książkowego i wydawniczego, a zarazem polimedialnego ${ }^{86}$ — pokazali, jak książka, zwłaszcza popularna, jawi się we współczesnej kulturze konwergencji jako komunikat „równoległy”, współistniejący w przekazie podobnych treści i emocji z innymi, zapisanymi w ,języku" medialnym. To „wieloadaptacyjne współistnienie” nie jest faktem obojętnym dla potencjalnej redefinicji samej książki, a także funkcjonowania jej systemu. Kategoria dokumentu piśmiennego i dla tego celu okazuje się bardziej otwarta i funkcjonalna. Ale czy wystarczająca? Konwergencja mediów prowadzi, jak dokumentują badacze, nie tylko do konwergencji postaci zapisu, lecz także sposobów odbioru ${ }^{87}$. Współczesna kultura niewątpliwie domaga się opisu współistnienia wielorakich postaci komunikacji książkowej i medialnej. Ma to istotne konsekwencje dla teorii bibliologicznej: czy głęboki charakter kulturowych przemian pozwoli poprzestać na założeniu komplementarności bibliologii z medioznawstwem ${ }^{88}$, bez istotnych w przyszłości rewizji teoretycznych i terminologicznych tej pierwszej? Zwłaszcza jeśli bibliologia nie chce pozostać nauką głównie historyczną. Odpowiedzi m.in. na te pytania twórczo poszukują np. Jadwiga Woźniak-Kasperek, Sebastian D. Kotuła, Małgorzata Kisilowska, M. Góralska ${ }^{89}$.

8. Paradygmat „kultura książki”, choć przyjmowany jako nowy ${ }^{90}$, miał swoje inspiracje w socjologii kultury Floriana Znanieckiego, w tekstach

Warszawa: SBP 2005, s. 39-57; Joanna PAPUZIŃSKA, Wpływ świata mediów na ksztalt książki dziecięcej i style jej odbioru, [w:] Książka dziecięca 1990-2005. Konteksty kultury popularnej i literatury wysokiej. Red. Grzegorz Leszczyński, Danuta Świerczyńska-Jelonek, Michał Zając, Warszawa: SBP 2006, s. 13-31; Anita HAS-TOKARZ, Problematyka książki dla dzieci i młodzieży i jej odbioru w obszarze współczesnej bibliologii - o potrzebie badań interdyscyplinarnych, [w:] Bibliologia i informatologia..., s. 111-124.

85 M. GÓRALSKA, Ksiązki, nowe media i ich czasoprzestrzenie, Warszawa: Wydaw. SBP 2009, s. 144; eadem, Kryzysy informacyjne, rewolucje..., s. 239-250.

86 A. HAS-TOKARZ, Horror w literaturze wspótczesnej i filmie, Lublin: UMCS 2010; Michał ROGOŻ, Fantastycznie obecne. Anglojęzyczne bestsellerowe cykle powieściowe dla dzieci i młodzieży we współczesnej polskiej przestrzeni medialnej, Kraków: Wydaw. Nauk. Uniwersytetu Pedagogicznego 2015.

87 Zob. np. Homo legens czy homo consumens? Czytelnik i książka w XXI wieku. Red. Anita Has-Tokarz, Renata Malesa, Lublin: Wydaw. UMCS 2014.

88 Por. K. MIGOŃ, Bibliologia wobec medioznawstwa...

89 Zob. artykuły w: Kulturowa tożsamość ksiązki. Pod red. Anny Cisło i Agnieszki Łuszpak, Wrocław 2014.

90 Gabriela ŽIBRITOVÁ, Metodologiczne problemy badań nad historia kultury ksiązki, Studia o Książce (5) 1975, s. 3-14; K. MIGOŃ, Bibliologia wśród innych nauk..., s. 13-24; idem, 'Kultura książki'... 
Jana S. Bystronia, potem Józefa Chałasińskiego, Jana Szczepańskiego, Antoniny Kłoskowskiej, Anny Pawełczyńskiej, Andrzeja Tyszki. Postulat, aby bibliologia obejmowała „całokształt kultury książkowej w przeszłości i teraźniejszości”, formułował S. Vrtel-Wierczyński, podobnie jak syntezę książki „z całością kultury materialnej i duchowej" postulował K. Głombiowski, a ambitnie realizowały dawne i nowsze historyczne prace ,polskiej szkoły bibliologii”, nierzadko wyprzedzając teoretyczne projekty głośnych później kierunków i badaczy zagranicznych ${ }^{91}$. K. Migoń wyznaczając bibliologii rozległy zakres, jako nauki „o świecie książek, o uniwersum książek, o książkowej cywilizacji” 92 , podejmował wielostronną krytykę tego paradygmatu otwierającego możliwość komplementarnego uwzględniania aspektów mentalnych, komunikacyjnych, technologicznych ${ }^{93}$. Definiując „kulturę książki”, odwoływał się do poglądu Paula Raabego, iż jest to: „,historycznie ukształtowany, obejmujący wielką część życia kulturalnego, aktywnie funkcjonujący całokształt obecności świata książek" 94 .

Ujęcie to, mimo że nie naruszyło klasycznego, triadycznego fundamentu procesu bibliologicznego (zapis, obieg, konsumpcja) ani też perspektywy funkcjonalnej, przyniosło jednak zasadniczą zmianę myślenia według „porządku antropologicznego" - to nie książka ,żyje”, lecz ludzie, żyjąc w kulturze, tworzą, wymieniają i czytają książki, kreują ,światy książek” — repertuary, biblioteki, mody czytelnicze, tworzą kulturę książki w jej wymiarze duchowo-intelektualnym, cywilizacyjno-materialnym i technologicznym. Dokonywała się swoista „antropologizacja” procesu bibliologicznego postrzeganego wcześniej głównie instytucjonalnie. Nie artefakt, lecz jego kulturowe pożytkowanie, nie tylko narzędzie społecznej komunikacji i proces komunikacyjny, lecz także relacje, interakcje i wartościowania ludzi w nim uczestniczących. Sprzyjało to przesunięciu „ostrości” w stronę zagadnień czytelnictwa, podobnie jak miało to miejsce w literaturoznawstwie budującym kulturową historię literatury ${ }^{95}$. Kulturowa teoria książki była rozwinięciem stosowanych wcześniej ujęć - funkcjonalnego i „komunikacyjnego"96. Wartością dodaną był wymiar aksjologiczny: książka jako podstawowa przestrzeń kreowania — petryfikowania i zmiany — kulturo-

${ }^{91}$ K. MIGOŃ, 'Kultura książki'..., s. 47; idem, Bibliologia historyczna..., s. 55; K. GŁOMBIOWSKI, O funkcjonalna koncepcję..., s. 24.

92 K. Migoń, Bibliologia wsród innych nauk..., s. 13.

93 Jak dowodził, „może ono pomieścić w sobie i skoncentrować wszystkie materialne i duchowe aspekty książki i świata książek [...] jako wytwory kultury duchowej, materialnej i technicznej [...]” (K. MIGOŃ, Bibliologia wśród innych nauk..., s. 13, 15).

94 K. MIGOŃ, Kultura książi. Program..., s. 16.

95 Zob. Kulturowa teoria literatury. Główne pojęcia i problemy. Red. Michał Paweł Markowski, Ryszard Nycz, Kraków: Universitas 2010 (zwłaszcza Anna BURZYŃSKA, Kulturowy zwrot teorii, s. 42-91); Kulturowa teoria literatury 2. Poetyki, problematyki, interpretacje. Red. Teresa Walas, Ryszard Nycz, Kraków: Universitas 2012.

96 J. Muszkowski i K. Głombiowski, każdy w inny sposób, akcentowali aspekty ,antropologiczne” (adekwatniejsze byłoby w tym wypadku określenie „,humanistyczne” czy „personalistyczne"). Pierwszy wskazywał na grupotwórczą rolę książki, powstawanie grup zawodowych - 
wych i społecznych wartości przez środowiska i wspólnoty w nich zakorzenione ${ }^{97}$. Już na początku lat 80. K. Migoń pisał: „Ośrodkiem problematyki bibliologicznej są [...] wzajemne, bogate i wielokierunkowe relacje książki i człowieka (grup społeczeństwa w ogóle)”98. Później określał bibliologię jako naukę: „o społecznej kulturze książki”, na którą składał się „Ogół zjawisk i procesów, zasobów materialnych i duchowych związanych z książką. Książki w ruchu, w działaniu [...], a także ich twórcy, właściciele i czytelnicy, tworzą specyficzną kulturę książki" "99. Opcja kulturowa w bibliologii nie redukowała tradycyjnych kategorii ani warsztatu badań księgoznawczych, nie tworzyła nowej struktury dyscypliny. Przeciwnie, łączyła na ,wewnętrznym” poziomie tę perspektywę z zagadnieniami dokumentologicznymi, bibliograficznymi, klasyfikacyjnymi, bibliotekoznawczymi.

Model badań empirycznych wyrastających z paradygmatu ,kultura książki” wypracowany został w środowisku historycznej bibliologii wrocławskiej już w latach 70. ${ }^{100}$ Zastosowała go m.in. Anna Żbikowska-Migoń, która procesy bibliologiczne tworzenia, komunikowania i upowszechniania piśmiennictwa naukowego w Polsce w okresie oświecenia ukazała w ścisłym związku z życiem umysłowym i społecznym środowiska twórców i zarazem odbiorców publikacji związanych z wileńskim ośrodkiem uniwersyteckim, wpisane w tkankę relacji zarówno instytucjonalnych, jak i nieformalnych ${ }^{101}$. Tę koncepcję kontynuowały następne pokolenia bibliologów. Bożena Koredczuk dała rozległy obraz życia z książką trzech pokoleń inteligencji prawniczej jako społeczności zintegrowanej systemem wartości (kulturalnych, intelektualnych, profesjonalnych), która podejmując role wydawców, księgarzy, bibliofilów, redaktorów, tworzy środowiskową kulturę

drukarzy księgarzy, krytyków, czytelników. Drugi — aspekt humanistyczny wiązał z moralnym i estetycznym wpływem treści, zmianami mentalności odbiorców

97 J. KOSTECKI, Czytelnik w świecie... Por. Problematyka aksjologiczna w nauce o literaturze. Studia. Red. Stefan Sawicki, Andrzej Tyszczyk, Lublin: Wydaw. KUL 1992; Andrzej TYSZKA, Kultura jest kultem wartości. Aksjologia społeczna - studia i szkice, Lublin: Norbertinum 1993.

98 K. MIGOŃ, Nauka o książce. Zarys problematyki... s. 144; idem, Bibliologia - nauka o kulturze książki, Nauka 2005, nr 2, s. 49-57; B. KOREDCZUK, Szkoła bibliologiczna, [w:] Wrocławskie środowisko akademickie. Twórcy i ich uczniowie. Red. Adam Chmielewski et. al., Wrocław: Zakład Narod. im. Ossolińskich 2007, s. 285-288; eadem, Wkład narodowych szkót badawczych: francuskiej, rosyjskiej i polskiej w rozwój współczesnej bibliologii, [w:] Książka, biblioteka, informacja - między podziałami a wspólnota. Red. Jolanta Dzieniakowska, Kielce: Wyd. Akademii Świętokrzyskiej 2007, s. 421-432.

99 K. MIGOŃ, Bibliologia wśród innych nauk..., s. 13; idem, 'Kultura ksiązki'..., s. 48.

100 K. MIGOŃ, Bibliologia historyczna ..., s. 48-49; Elżbieta HERDEN, B. KOREDCZUK, Badania naukowe w Instytucie Informacji Naukowej i Bibliotekoznawstwa Uniwersytetu Wroclawskiego w latach 1956-2006. Próba syntezy i oceny, [w:] Dokument, ksiażka i biblioteka..., s. 181-200; K. MIGOŃ, Pół wieku Instytutu Informacji Naukowej i Bibliotekoznawstwa Uniwersytetu Wrocławskiego (1956-2006), [w:] Dokument, ksiązka i biblioteka..., s. 169-179.

101 A. ŻBIKOWSKA-MIGOŃ, Książka naukowa w kulturze polskiego Oświecenia, Warszawa-Wrocław: Państwowe Wydaw. Naukowe 1977. 
książki: repertuary lektury, kryteria wartościowania świata książek i użytkowania go $^{102}$. Janusz S. Gruchała, przedstawiając świat książki renesansowych humanistów, zarysowuje najpierw fundamenty aksjologiczne leżące u podstaw wyobrażeń, motywacji, relacji, jako fundament całego, także materialnego zorganizowania „świata książek” tej społeczności ${ }^{103}$.

Ujęcia ,antropologizujące” w humanistyce wyrastały z różnych przesłanek filozoficznych i naukowych ${ }^{104}$. Te, które nawiązywały do etnologii i teorii ewolucjonizmu, formułowały pytania, mówiąc najogólniej, związane z „biologicznym podłożem nauk społecznych", a w odniesieniu do zagadnień lektury — uwydatniały jej uwarunkowania i aspekty materialne oraz somatyczne. Inny kierunek przyjmowały te, których podłożem był personalizm i nurty hermeneutyczne: wówczas to „Geistiger Inhalte” (do czego odwoływał się także P. Raabe) wpływały na treściowe, formalnogatunkowe i organizacyjne cechy całego procesu kulturowej komunikacji. W ostatnich latach różne aspekty myślenia w kategoriach antropologiczno-kulturowych, ogólnie bliższe jednak inspiracjom personalistycznym, proponowali na gruncie bibliologii zwłaszcza A. Dróżdż, J. Kostecki i Roman Chymkowski ${ }^{105}$. Jeszcze inne pojawiały się w pracach dotyczących symboliki książki ${ }^{106}$.

„Kultura książki” jako perspektywa badawcza sprzyjała także ujęciom „regionalnym”107. Istotny wkład teoretyczny i metodologiczny wniosła Maria Kocójowa, podejmując krytykę metody topograficznej dla badań dziejów książki, dokumentując przestrzenne usytuowanie instytucji książki w Krakowie w powią-

102 B. KOREDCZUK, Udział inteligencji prawniczej Królestwa Polskiego w kształtowaniu kultury książki (1815-1915), Wrocław: Wydaw. Uniwersytetu Wrocławskiego 2011.

103 Janusz S. GRUCHAŁA, Iucunda familia librorum. Humaniści renesansowi $w$ świecie książki, Kraków: Universitas 2002.

104 Ponieważ nazwa używana jest tutaj sensu largo, a nie tylko w odniesieniu do antropologii kulturowej jako dyscypliny, stosuję cudzysłów.

Zob. np. Zanikajace granice. Antropologizacja nauki i jej dyskursów. Red. Adam Pomieciński i Sławomir Sikora, Poznań: Biblioteka Telgete Wydaw. 2009; Maciej MARYL, Antropologia odbioru literatury - zagadnienia metodologiczne, Teksty Drugie. Teoria literatury, krytyka, interpretacja 2009, nr 1/2, s. 228-251; Hanna MAMZER, Przemoc i tekst, [w:] Formy przemocy w kulturze współczesnej. Red. naukowa Hanna Mamzer, Poznań: Wydaw. Nauk. Uniwersytetu Adama Mickiewicza 2006, s. 27-43.

105 A. DRÓŻDŻ, Książki i biblioteki w perspektywie antropologii kulturowej, [w:] Bibliologia i informologia..., s. 65-79; idem, Utopie jako element zrozumienia społecznych funkcji ksiażki, [w:] Ksiażka ponad podziałami. Pod red. Antoniego Krawczyka, Lublin: Wydaw. Uniwersytetu Marii Curie-Skłodowskiej 2007, s. 33-47; Roman CHYMKOWSKI, $W$ stronę antropologii praktyk lekturowych, Kultura i Społeczeństwo (55) 2011, nr 2/3, s. 261-268; J. KOSTECKI, Czytelnik w świecie... Zob. też K. MIGOŃ, Bibliologia wobec medioznawstwa..., s. 15.

106 Np. Juliusz DOMAŃSKI, Tekst jako uobecnienie. Szkic z dziejów myśli o piśmie i książce, Kęty: Wydaw. Antyk 2002; Alina DZIĘCIOŁ, Książka jako symbol w kulturze polskiej XVII wieku, Warszawa: Zamek Królewski „Arx Regia” 1997.

107 B. BIEŃKOWSKA, Badania regionalne w historiografii książki, Studia o Książce (17) 1988, s. 17-33. 
zaniu z innymi ośrodkami życia naukowego i kulturalnego ${ }^{108}$. Jej prace nie tylko dawały fundament historycznej geografii książki, lecz także w istotnej mierze torowały drogę ujęciom kulturowym, przesuwając pole widzenia z ,życia książki”" na relacje, więzi i działania „ludzi książki” jako rzeczywistego faktora lokalnych procesów bibliologicznych.

9. Teoria sztuki książki oraz badania nad estetyką książki prowadzone pod kierunkiem Małgorzaty Komzy we wrocławskim środowisku bibliologicznym mają również swe źródło w kulturowym paradygmacie. Idee książki pełniącej społeczne funkcje jako integralna jakość estetyczna obecne były w myśli Muszkowskiego i Głombiowskiego ${ }^{109}$. W ostatnim zwłaszcza okresie podejmowane są studia nad sztuką książki w perspektywie „poetyki odbioru”, poszukujące semiotycznych elementów struktury estetyczno-typograficznej, istotnych w dia$\operatorname{logu} \mathrm{z}$ czytelnikiem, w społecznym obiegu ${ }^{110}$. M. Komza - w odróżnieniu od innych badaczy analizujących przede wszystkim strukturalne elementy estetyki książki oraz wkład ilustratorów i typografów ${ }^{111}$ — wypracowała na fundamencie teorii funkcjonalnej oryginalną, spokrewnioną z nurtami myśli zagranicznej, głównie francuskiej, szkołę badań nad estetyką książki. Otworzyła nowe pola interpretacji: na pograniczu sztuki typograficznej, sztuk plastycznych i wizualnych, całej komunikacji kulturowej, której medium stanowi obraz. Przestrzeń wizualną książki: „związki między ilustracją i tekstem”, „relacje, jakie zachodzą między poszczególnymi elementami książki oraz jej oddziaływanie na odbiorcę", zmieniające się kanony „kształtowania kompozycji graficznej i typograficznej wybranych typów edycji”, „odbiór ilustracji [...] jak i reakcji na dzieło jako całość”112

108 Maria KOCÓJOWA, Krakowski świat książki doby autonomii galicyjskiej (kształtowanie się nowego modelu w latach 1867-1882), Kraków: Uniwersytet Jagielloński 1990; eadem, Nowe oferty dla badań dziejów polskiej ksiązki w okresie zaborów, [w:] Książka polska w okresie zaborów. Wybrane problemy metodologii i dydaktyki bibliotekoznawstwa i informatologii. Pod red. Marii Kocójowej, Kraków: Universitas 1991, s. 13-39; eadem, W poszukiwaniu modelu badań dziejów ośrodków książki polskiej, Roczniki Biblioteczne (27) 1983, z. 1/2, s. 375-407. Można dodać, że model badań łączących kulturalną działalność człowieka ze środowiskiem geograficznym pojawił się na gruncie francuskiej szkoły historiograficznej Annales.

109 M. KOMZA, Jan Muszkowski o sztuce ksiażki, [w:] Jan Muszkowski..., s. 57-71; K. GŁOMBIOWSKI, Ksiażka w procesie komunikacji..., zwłaszcza s. 39-108.

110 Zob. np. liczne rozprawy w tomie Sztuka ksiażki. Historia - teoria - praktyka. Red. Małgorzata Komza, Wrocław: Wydaw. Uniwersytetu Wrocławskiego 2003.

111 Np. Janina WIERCIŃSKA, Sztuka i ksiązka, Warszawa: PWN 1986; Ewa CHOJECKA, Ilustracja polskiej książki drukowanej XVI i XVII w., Warszawa: KAW 1980; eadem, Stan badań nad historia sztuki ksiażkowej w Polsce. Uwagi o metodologii badawczej, Studia o Książce (12) 1982, s. 19-32; Maria GROŃSKA, Grafika w książce, tece i albumie. Polskie wydawnictwa artystyczne i bibliofilskie z lat 1899-1965, Warszawa-Kraków: Zakład Narod. im. Ossolińskich 1994; Katarzyna KRZAK-WEISS, Ilustracja polskiej ksiązki drukowanej od XV do XVIII wieku. Zarys stanu badań i postulaty badawcze, [w:] Bibliologia. Problemy badawcze..., s. 142-152.

112 M. KOMZA, Estetyka i sztuka książki w badaniach bibliologicznych, [w:] Teoretyczne zagadnienia bibliologii i informatologii..., s. 37, 39.

Roczniki Biblioteczne 60, 2016

(C) for this edition by CNS 
widzi w szerokim kontekście zjawisk wyrażających „estetyczną wyobraźnię” społeczeństwa, łączy z praktyką żywych obrazów, przedstawień teatralnych, widowisk, wystaw, życiem obyczajowym (książka-podarek, książka-teatrzyk, album), technologią (fotografia, muralia). Bogate źródłowo prace M. Komzy łączą dwie dopełniające się perspektywy badawcze: jak w historycznym rozwoju form kultury estetycznej kształtowały się różnorodne pod względem edytorskim i funkcjonalnym postacie dokumentów (książek), lecz także — jaki był udział sztuki książki w kształtowaniu kanonów estetycznych i stylu życia, mentalnych pojęć i standardów estetycznych epoki ${ }^{113}$. Preferując rzetelne studia badawcze, dostrzegając skomplikowaną materię przedmiotu, a nawet definicyjną niejednoznaczność wielu pojęć, M. Komza zmierza w ostatnich latach w kierunku teoretycznych podsumowań dotyczących miejsca tej problematyki w bibliologii, a także koniecznych odniesień interdyscyplinarnych ${ }^{114}$. Jest to propozycja formułowana ostrożnie na gruncie teorii funkcjonalnej, podczas gdy rozległe perspektywy empirycznych badań autorki twórczo te granice przekraczają, ku ścisłym powiązaniom historii książki z życiem umysłowym i obyczajowym, z całą kulturą obrazu, w jej aspektach semiotycznych i rzeczowych. Ważne studium teoretyczno-metodologiczne w odniesieniu do tej problematyki dał także K. Migoń ${ }^{115}$.

Podsumowującą ten zarys konkluzję poprzedzić wypada kilkoma przynajmniej spostrzeżeniami odnośnie do przestrzeni teoretycznych dyskusji, jaką tworzyły naukowe czasopisma bibliologiczne oraz tomy prac zebranych poświęcone teorii dyscypliny, liczne zwłaszcza w ostatnim piętnastoleciu. Rozwijały one teorię dyscypliny, podejmując ważne problemy szczegółowe, np. dotyczące, oprócz już wymienionych, badania popularności dzieła i pisarza (A. Żbikowska-Migoń), problematyki metodologicznej i źródłoznawczej w bibliologii (m.in. K. Migoń, A. Żbikowska-Migoń, Piotr Dymmel), filozoficznych źródeł teorii księgoznawczej (Andrzej Nowicki, Agnieszka Luszpak, M. Góralska), metodologii współczesnych i historycznych badań czytelnictwa (Teresa Radwan-Wińska, J. Kostecki), wykorzystania w bibliologii źródeł literackich i biograficznych (Małgorzata Stolzman, Wiesław Bieńkowski, Krystyna Bednarska-Ruszajowa, S. Siekierski, Anna Gruca, B. Koredczuk, R. Chymkowski).

113 M.in. M. KOMZA, Żywe obrazy...; eadem, Książka z teatrem związana, Roczniki Biblioteczne (47) 2003, s. 89-120; eadem, Książka ilustrowana w oczach XIX-wiecznych odbiorców, Rocznik Gdański (61) 2001, z. 2, s. 219-227.

114 M. KOMZA, Bibliolog wobec nowych zjawisk w sztuce ksiażki, [w:] Centrum i pogranicze w polskiej kulturze wydawniczej i czytelniczej (wybrane aspekty badań bibliologicznych i szkice historyczne). Red. Elżbieta Gondek, Irena Socha, Studia Bibliologiczne (17), Katowice 2008, s. 29-41; eadem, Estetyka książki w badaniach bibliologicznych, [w:] Bibliologia i informatologia..., s. 57-64; eadem, Estetyka i sztuka ksiązki..., s. 31-42.

115 K. MIGOŃ, Nauka o książce. Zarys..., s. 121-123; idem, Bibliologiczne problemy książki ilustrowanej, [w:] Sztuka ksiązki. Historia - teoria — praktyka..., s. 13-22. 
„Studia o Książce” (t. 1-19, 1970-1993) nazwać można laboratorium teoretycznym dyscypliny ${ }^{116}$. Tam ukazywały się teksty wyznaczające przedmiot i zakres badań, stanowiące zapowiedź późniejszych, ważnych książek naukowych (K. Głombiowskiego, K. Migonia, A. Żbikowskiej-Migoń, A. Nowickiego, R. Cybulskiego, S. Siekierskiego, Zofii Gacy-Dąbrowskiej, B. Bieńkowskiej i wielu innych), a także kształtujących się kierunków metodologicznych (np. już w połowie lat 70. pojawia się kategoria „kultura książki” w artykule Gabrieli Žibritovej, A. Nowicki wprowadza problematykę ikonologiczną, a J. Franke poddaje krytyce sposoby posługiwania się kategorią środowiska społecznego w badaniach czytelnictwa ${ }^{117}$ ). Naukowe dyskusje, nieliczne, dotyczyły metodologicznych pryncypiów, jak te prowadzone przez K. Głombiowskiego ${ }^{118}$. Ważne były numery poświęcone stanom i potrzebom badań subdyscyplin bibliologii (sztuki książki, mecenatu wydawniczego, edytorstwa, historii bibliofilstwa i czytelnictwa) - jak np. tom 12 (1982) otwarty przez K. Migonia obszernym artykułem Gtówne kierunki i perspektywy teorii księgoznawstwa, a zamknięty polemiką K. Głombiowskiego z niektórymi tezami Escarpita i Żółkiewskiego (Que pouvous-nous faire de la littérature?) czy tom 15 (1985) poświęcony problematyce źródłoznawczej w bibliologii lub późniejszy o trzy lata, zapowiadający temat przewodni artykułem K. Migonia (Badania regionalne $w$ historiografii ksiażki).

W „Rocznikach Bibliotecznych”, przynoszących obszerne źródłowe prace badawcze, artykuły teoretyczne również systematycznie się pojawiały. Częściej dotyczyły one metodologicznych aspektów bibliologicznych subdyscyplin, jak np. teksty: K. Migonia (Pismo jako przedmiot badań humanistycznych), M. Kocójowej (W poszukiwaniu modelu badań dziejów ośrodków książki polskiej), Elżbiety Zawiszy (O przydatności nauki o ksiażce w badaniach literackich...), Jacka Wojciechowskiego (Biblioteka jako wielosemiotyczne medium komunikacji społecznej), Jerzego Ratajewskiego (Czwarty raz o bibliotekoznawstwie. Rozważania metodologiczne), Marty Skalskiej-Zlat (Bibliometria - pojęcia, metody, kierunki badań), Kazimiery Maleczyńskiej (Założenia metodologiczne przyszłej historii książki, bibliotek i czytelnictwa na Śląsku), Jadwigi Andrzejewskiej (Pojęcie kultury czytelniczej...), K. Bednarskiej-Ruszajowej ( $Z$ metodologicznych problemów badań nad czytelnictwem okresu Oświecenia), Stanisława Grzeszczuka (Świadectwa odbioru jako źródła bibliograficzne) ${ }^{119}$. Po roku 2000 pojawiły się nowe problemy: biblioterapii (Małgorzata Czerwińska, Tomasz Kruszewski) oraz audiowizualnych kontekstów książki (M. Góralska, Aleksander Radwański), historii czytelnictwa

116 Por. artykuł M. DERKACZ, A. ŁUSZPAK „Studia o Książce” (1970-1993) - koncepcje programowe i ich realizacja $\mathrm{w}$ niniejszym tomie.

117 G. ŽIBRITOVÁ, op. cit., s. 3-14; Andrzej NOWICKI, O czytaniu obrazów i czytaniu na obrazach, Studia o Książce, s. 3-14; Jerzy FRANKE, Problematyka środowiska społecznego w badaniach czytelnictwa, Studia o Książce (8) 1978, s. 159-196.

118 Np. K. GŁOMBIOWSKI, O dwóch tendencjach badań..., s. 3-16.

119 Przykłady wybrane z Roczników: 27 (1983), 32 (1988) i 35 (1991). 
— np. obszerne przeglądy prac zagranicznych pióra A. Zdanowicz. „Roczniki”, podobnie jak „Studia”, prowadziły dział recenzji publikacji zagranicznych i krajowych, przyczyniając się do kształtowania tożsamości dyscypliny w rozległym, europejskim kontekście ${ }^{120}$.

Odpowiedzią na konstatację B. Bieńkowskiej u progu nowego stulecia o potrzebie aktualnych prac teoretycznych ${ }^{121}$ były dosyć liczne w następnych latach konferencje naukowe o tym charakterze ${ }^{122}$ oraz tomy zbiorowe będące zwykle ich pokłosiem ${ }^{123}$. Sui generis znakiem teoretycznej dojrzałości dyscypliny są publikacje o charakterze monograficznym, weryfikujące wybrany problem czy kategorię (np. bibliologia polityczna, kulturowa tożsamość książki) ${ }^{124}$, w przekroju subdyscyplin bibliologicznych oraz w odniesieniu do kontekstów międzydyscyplinarnych. Z pewnością znacząca dynamika ukazywania się publikacji poświęconych w znacznej części zagadnieniom teoretycznym i metodologicznym bibliologii jest świadectwem żywotności i rozwoju dyscypliny twórczo wyodrębniającej nowe i redefiniującej dawne pola badawcze.

Zarysowane tutaj przedstawienie najczęściej uprawianych kierunków i związanych z nimi kategorii nie wyczerpuje różnorodności księgoznawczych poszukiwań. Pozwala jednak najogólniej zauważyć, jak poszerzał się zakres dyscypliny: wyznaczała go książka jako fenomen piśmienniczo-wydawniczy (edytorski), potem książka jako proces bibliologiczny oraz jej funkcja społeczna, książka w kontekstach polimedialnego komunikowania, a wreszcie społeczne relacje, działania i wartościowania tworzące kulturę książki. Zmieniało się „używanie" kategorii organizujących proces badawczy, np. sytuację komunikacyjną rozumiano wpierw „behawioralnie” — jako zależną od uwarunkowań społeczno-cywilizacyjnych, struktury społecznej i instytucjonalnego zorganizowania, a z czasem jej wyróżnikiem stawało się również „doświadczenie” w wymiarze mentalnym (,mapy konceptualne”, habitusy), obyczajowym, a nawet somatycznym, w powiązaniu ze sferą wartości i motywacji, czego konsekwencją było m.in.

$120 \mathrm{Z}$ konieczności trzeba $\mathrm{w}$ tym miejscu pominąć wkład innych czasopism naukowych, które licznie się pojawiły wraz z rozwojem regionalnych ośrodków akademickich. Naukoznawczo-prasoznawcze studium czasopism i wydawnictw ciągłych obrazujących rozwój badań księgoznawczych zasługuje na osobną monografię.

121 B. BIEŃKOWSKA, Bibliologia i okolice..., s. 44.

122 Np. Od ksiązki dawnej do biblioteki wirtualnej - przeobrażenia bibliologii polskiej. Na marginesie trzydziestolecia Instytutu Informacji Naukowej i Bibliologii Uniwersytetu Mikotaja Kopernika w Toruniu. Ogólnopolska konferencja naukowa. Toruń 23-24 października 2007 (sprawozdanie w Rocznikach Bibliotecznych (52) 2008).

123 M. in. Wiedza o ksiażce w nauce i dydaktyce... (zwłaszcza artykuły K. MIGONIA, Bibliologia w świecie oraz B. BIEŃKOWSKIEJ, Zastosowania i konteksty wiedzy o ksiażce); Nauka o książce, bibliotece i informacji...; Bibliologia. Problemy...; Dokument, ksiażka i biblioteka...; Bibliologia i informatologia...; Teoretyczne zagadnienia bibliologii...; Ksiażka i biblioteka w procesie komunikacji społecznej...

124 Bibliologia polityczna...; Kulturowa tożsamość książki... 
dowartościowanie odbiorcy (odbioru) potocznego ${ }^{125}$. Coraz głębiej definiowano funkcje książki: początkowo jako transmisję oraz wpływ treści (i formy) na odbiorców, potem wiązano je z instytucjami systemu książki, w końcu dowartościowano podmiotową rolę publiczności jako nadającej i weryfikującej funkcje. Podobnie ujęcie komunikacyjne, deklarowane we wszystkich niemal teoretycznych stanowiskach, było rozumiane jako: komunikowanie treści książki przez jej edytorskie wyposażenie, społeczny proces komunikacji piśmiennej, komunikacyjny porządek procesu bibliologicznego czy komunikacyjna rola wybranych instytucji książki, interakcje ludzi książki w ich wymiarze symbolicznym i instytucjonalnym. Poszukiwano również miejsc wspólnych komunikacji literackiej i komunikacji informacyjnej jako dwóch różnych systemów komunikacji społecznej ${ }^{126}$. Punkt ciężkości przenosił się więc w bibliologicznym myśleniu z samej książki jako kulturowego artefaktu oraz jej ,życia”, czyli procesu bibliologicznego i jego instytucji, na funkcje książki wobec publiczności w procesie społecznej i kulturowej transmisji, a w końcu na publiczność jako kreatora i użytkownika kultury książki, której działania znajdują „zapis” w dokumentacji bibliologicznej. Koncepcje bibliologiczna i socjokulturowa, traktowane początkowo jako odrębne czy nawet przeciwstawne, stawały się komplementarne ${ }^{127}$.

O rozwoju danej nauki kształtującej własną teorię świadczy „żywotność adaptacyjna" - gdy oprócz tradycyjnych, tworzących fundament dyscypliny, stale „próbowane” są i adaptowane do jej instrumentarium nowe kategorie. Świadczy także zachowanie równowagi między teoretycznym constans — stanowiącym jej myślowy i metodologiczny fundament — a poszukiwaniami i inspiracjami, które ją oświetlają w nowy sposób: „Wielość tak różnych punktów widzenia w studiach nad książką ma tę zaletę, że pozwala na gromadzenie coraz pełniejszej wiedzy o tym fenomenie ludzkiej cywilizacji"128. Rodzima bibliologia otwarta na inspiracje nauk pokrewnych, lecz adaptująca je krytycznie, unikała zarówno pułapki eklektyzmu, jak i niebezpieczeństwa izolacji. Zdobyła naukową tożsamość dyscypliny otwartej, niezbędnej dla innych badań humanistycznych ${ }^{129}$, z których sama musi czerpać dla poznania własnego rozległego pola badawczego.

125 Por. Anna FRANASZEK, O sposobach pojmowania literatury przez czytelnika, Rocznik Biblioteki Narodowej (19) 1997, s. 153-163.

126 Agnieszka KORYCIŃSKA-HURAS, Informacyjny kontekst komunikacji literackiej, Kraków: Wydaw. Uniwersytetu Jagiellońskiego 2006.

127 K. GŁOMBIOWSKI, O dwóch tendencjach...; Por. Teresa RADWAN-WIŃSKA, Z problemów wspótczesnej refleksji naukowej wobec badań nad czytelnictwem, Roczniki Biblioteczne (27) 1983 , z. 1-2, s. 435-452.

128 K. MIGOŃ, Bibliologia wśród innych nauk..., s. 14. Podobną opinię wyraziła B. BIEŃKOWSKA: „Bibliologia jawi się w ich [innych nauk] świetle nie tylko jako całkowicie ukształtowana samodzielna dyscyplina naukowa, ale też stale rozszerzająca zakres swoich kompetencji" (Bibliologia dyscyplina rozwojowa..., s. 15).

129 Zob. np. B. BIEŃKOWSKA, Metody bibliologiczne w badaniach dziejów nauki, Kwartalnik Historii Nauki i Techniki (29) 1989, nr 2, s. 331-342. 
O rozwoju dyscypliny świadczy ponadto współbrzmienie z problemami aktualnie dyskutowanymi w naukach pokrewnych. Podobne jak w nauce o książce, kierunki teoretycznych poszukiwań właściwe były całej humanistyce, nie tylko penetrowano pokrewne pola badawcze, zapożyczając kategorie i metody, lecz przede wszystkim przyjmowano podobne założenia teoretyczne ${ }^{130}$. Być może interdyscyplinarne badania humanistyczne ${ }^{131}$ zmierzają ku metadyscyplinie o funkcjonowaniu człowieka (społeczności) w kulturze pisma i obrazu, jednoczącej wysiłki wielu nauk z ich specyficznym potencjałem warsztatowym i pojęciowym? Także wówczas książka (dokument piśmienniczy) — jako jedna z głównych postaci materializacji kultury symbolicznej, a zarazem aksjologicznie nacechowany system kulturowej i społecznej komunikacji — oraz bibliologia ze specjalistycznym warsztatem badań księgoznawczych i dokumentologicznych musiałyby zająć miejsce istotne ,jako pełnoprawny partner w inter- i multidyscyplinarnych badaniach humanistycznych (z koniecznymi »wyjściami« poza humanistykę)""132.

O rozwoju nauki świadczy w końcu zdolność „zrodzenia” nowych kierunków badawczych i dyscyplin. Zarówno bibliotekoznawstwo, jak informologia - obecnie dyscypliny samodzielne - czerpały z teoretycznych doświadczeń bibliologii. „Polska szkoła bibliologii”, łącząc już u progu XX wieku, zwłaszcza w badaniach historycznych, analizę zjawisk społecznych z perspektywą kulturową, dowartościowując aspekty ,antropologiczne” $i$ aksjologiczne, nierzadko wyprzedzała, a co najmniej towarzyszyła zmierzającym w podobnym kierunku dyskusjom teoretycznym oraz pracom badawczym za granicą. Pierwszorzędny wkład w inicjowanie nowych dróg, kategorii i aspektów badań księgoznawczych oraz w powstawanie monografii stanowiących ich modelowe realizacje dała bibliologia wrocławska.

IRENA SOCHA

BOOK SCIENCE IN POLAND IN 1945-2015. THEORETICAL SOURCES OF INSPIRATION

\section{Summary}

The aim of the paper is to paint a retrospective panorama of the theoretical legacy of the post-war Polish book studies. Of key importance to the author is the question of the subject of

$130 \mathrm{~Np}$. w nauce o literaturze: od historii tekstów i biografii autorów, przez dzieje życia literackiego, poetykę odbioru po kulturową teorię literatury harmonizującą w perspektywie antropologicznej zagadnienia twórczości, obiegu i odbioru.

131 Zob. np. Lech WITKOWSKI, Wstęp do problemu fenomenologii czytania, [w:] Między pedagogika, filozofia i kulturą. Studia, eseje, szkice, Warszawa: Instytut Badań Edukacyjnych 2007; Katarzyna SZCZEŚSIAK, Okładka i obwoluta książki jako przedmiot badań interdyscyplinarnych, Toruńskie Studia Bibliologiczne (7) 2011, nr 2, s. 29-41; Marcin RYCHLEWSKI, Ksiażka jako towar. Książa jako znak. Studia z socjologii literatury, Gdańsk: Wydawnictwo Naukowe Katedra 2013.

132 K. MIGOŃ, Bibliologia wśród innych nauk..., s. 24. 
the discipline and, consequently, its scope. The author discusses directions in book studies and the bibliological process making up, starting in the 1930s and with Jan Muszkowski's concept, the core tradition and foundation of the theories of book studies: theories built around the paradigm of "life of the book" seeing it as an integrally defined process of production, dissemination and consumption; Karol Głombiowski's functional theory, thanks to which "systemic" and "functional" approaches have become a commonly accepted methodological premise in book studies; concepts formulated by Janusz Dunin, who linked the bibliological tradition of historical, source studies of editorial forms of books with the functional theory and "communication" perspective; theory formulated by Radosław Cybulski, who, in combining the established morphology of the book with a semiotic and communication perspective, adopted "book consumption", i.e. an integrated system of satisfying the needs of book users, as a functional category to describe the behaviour of participants in the book market; concepts focused on the "social communication situation" as a research category and perspective stemming from a sociological and semiotic reorientation of humanistic thinking. At the end the author discusses trends which in recent years have considerably expanded research perspectives: books in the media space; the "culture of the book" paradigm, which is conducive to an "anthropologisation" of the bibliological process, perceived no longer only institutionally, from the perspective of social communication, but also through relations, interactions and value judgements of people participating in it, which shifts research priorities towards the questions of reading and often also towards "regional" approaches; theory of book art and research into book aesthetics. At the various stages of the development of bibliology and depending on the research perspective, the focus shifted from the book as a cultural artefact and its "life", i.e. bibliological process with its institutions, to functions of the book with regard to the public in the process of social and cultural transmission, and, finally, to the public as the creator and user of the culture of the book, the actions of which are "recorded" in bibliological documentation.

KEY WORDS: bibliology, theory of bibliology, methodology of bibliology, disciplines related to bibliology, Polish bibliological school 